\title{
Screening for Cervical Cancer - Minimise Risks - Maximise Benefits. Need for Adaptation in Germany in Light of the European Guidelines and Their Objectives
}

\author{
Früherkennung Zervixkarzinom: Risiken minimieren - Nutzen maximieren. \\ Anpassungsbedarf in Deutschland mit Blick auf die Europäische Leitlinie und deren Zielsetzung
}

Authors

Affiliations
E. Simoes ${ }^{1}$, S. Brucker ${ }^{1}$, M. W. Beckmann ${ }^{2}$, O. Ortmann ${ }^{3}$, C. Albring ${ }^{4}$, D. Wallwiener ${ }^{1}$

The affiliations are listed at the end of the article.

Key words
cervical cancer
cervix
precancerous cervix
cancer register
gynaecology
Schlüsselwörter
Zervixkarzinom
Zervix
Zervixpräkanzerose
- Krebsregister
- Gynäkologie

received 24.4.2013

revised 24.4.2013

accepted 15.5.2013

\section{Bibliography}

DOI http://dx.doi.org/

10.1055/s-0032-1328687

Geburtsh Frauenheilk 2013; 73 :

623-639 ๑ Georg Thieme

Verlag KG Stuttgart · New York

ISSN 0016-5751

\section{Correspondence}

\section{Prof. Dr. med. Elisabeth}

Simoes

Universitätsfrauenklinik

Tübingen

Institut für Frauengesundheits-

forschung

Calwer Straße 7

72076 Tübingen

simoes@t-online.de

\section{Abstract}

$\nabla$

The national cancer plan calls for adjustment of the early detection scheme for cervical cancer to the quality requirements of the "European guidelines for quality assurance in cervical cancer screening". The existing scheme should be further developed and carried out in an organized, population-based framework. The objective is to lower the incidence and mortality of cervical cancer while minimising the risks and optimising the benefits of the scheme. The self-determined choice of the patients should be respected. The competence for this task falls in the medical field of activity. The adaptation includes an organisational further development and, in part, re-organisation of the established early detection scheme for cervical cancer. If the national cancer plan is considered as a concept for the discursive further development of the healthcare, the experts from different areas of the system are encouraged to participate. To go to a new version of the national directive for early detection of cancer that will define the procedure in the Federal Republic in future first requires a consensus of the fields of action with regard to the specified objectives of the transformation. The heterogeneity of the approaches in Europe (even within individual countries) as well as the results clearly show that Germany has to find and define its own pathway. The presented overview of the pending fields of action could serve as a basis for the development process and the work of a multisectoral task force in the field of gynaecology.

\section{Zusammenfassung \\ $\nabla$}

Der nationale Krebsplan sieht die Anpassung der Zervixkarzinom-Früherkennung an die Qualitätsvorgaben der „Europäischen Leitlinien für die Qualitätssicherung des Zervixkarzinom-Screenings“ vor. Dazu soll das bestehende Angebot weiterentwickelt und in einem organisierten, bevölkerungsbezogenen Rahmen durchgeführt werden. Ziel ist eine weitere Senkung der Inzidenz und Mortalität des Zervixkarzinoms bei Minimierung der Risiken und Optimierung des Nutzens des Verfahrens. Der selbstbestimmten Entscheidung der Patientin soll Raum gegeben werden. Die Befähigung hierzu fällt in den ärztlichen Aufgabenbereich. Die Anpassung beinhaltet eine organisatorische Weiterentwicklung und teilweise Neuorganisation der etablierten Zervixkarzinom-Früherkennung. Versteht man den Nationalen Krebsplan als Konzept einer diskursiven Weiterentwicklung der Versorgung, so sind die Expert/innen aus den unterschiedlichsten Bereichen des Versorgungssystems zur Mitwirkung aufgefordert. Um im Prozess hin zu einer Neufassung der Früherkennungs-Richtlinie, die das Vorgehen in der Bundesrepublik festlegen wird, mitgestalten zu können, bedarf es zunächst eines Konsenses über die Handlungsfelder mit Blick auf die vorgegebene Zielsetzung der Umgestaltung. Die Heterogenität der Ansätze in Europa (selbst innerhalb einzelner Länder), ebenso wie der Ergebnisse, lassen deutlich werden, dass Deutschland seinen eigenen Weg suchen und definieren muss. Die vorgestellte Zusammenschau anstehender Handlungsfelder könnte als Grundlage für den Findungsprozess und die Arbeit einer sektorübergreifenden Task Force im Fachgebiet Gynäkologie dienen. 


\section{Introduction}

$\nabla$

After several years of preparation since 2008, the national cancer plan was published at the beginning of 2012 [1], and legislation for opening the way to implementation was initiated [2]. Both also concern the screening for cervical cancer. Screening for cervical cancer has been a part of the directive for early detection of cancer for many years [3] (based on version of the Federal Committee of Doctors and Health Insurances dated 01.07.1971). The process established in Germany [4] should be developed further in orientation on the European Guidelines [5]. The aim of this new organisation is a further reduction in the incidence and mortality of cervical cancer in Germany while minimising the risks and optimising the benefits of the procedure - in pursuance of the aims reflected in the legislation for the further development of cancer early detection and quality assurance through clinical cancer registers (Krebsfrüherkennungs- und -registergesetz - KFRG) [6]. The German Parliament passed the legislation for the further development of cancer screening and quality assurance through clinical cancer registers (Krebsfrüherkennungs- und -registergesetz KFRG) on 31.01.2013 [7] and it came into force on 10.04.2013.

The changes that will therefore be needed will finally be elaborated and defined in a respective procedure by the Federal Joint Committee (FJC). The regulations create a judicial framework and a clear allocation of tasks for the Federal Joint Committee which is responsible for the content and organisational structuring of cancer early detection in its directives. The Federal Joint Committee and the joint self-management are obligated to change the existing early detection scheme for cervical cancer into an organised cancer early detection programme.

The respective views and ideas are very different even within the medical specialty gynaecology and obstetrics [8-10]. Only a factually justified and evidenced-based road map can show the way $[11,12]$.

This approach is also outlined explicitely by the draft of the law for the further development of cancer screening and for quality assurance through clinical cancer registers. The Federal Joint Committee has, on closer definition of the organised cancer early detection programme, appropriately to take the recommendations of the respective European guidelines into consideration. The European guidelines - as in general for medical guidelines - are not rigid and strictly binding requirements but rather scientific and technical orientation aids in the sense of "corridors for decision making", from which the Federal Joint Committee may deviate in clearly and duly substantiated cases. In any case the European guidelines are formulated in such a way that the individual member states are allowed a reasonable assessment scope for the national structuring of their cancer screening programmes. Thus there remains a principle scope of action for national recommendations and guidelines. However, in the structuring of an organised cancer early detection programme the Federal Joint Committee is obliged to take the current state of medical knowledge into consideration which thus acquires an action-guiding character. This includes, besides the European guidelines, also other qualitatively high-value and evidence-based national and international guidelines and studies. Accordingly, the adaptation to the German framework conditions and the inclusion of the latest state of knowledge are explicitly required in the transformation of the procedures used for early detection of cervical cancer. This means that for differing practices and new developments such as, for example, the availability of HPV vaccines (HPV vaccinations [human papilloma virus] were recommended in Germany in

\section{Einführung}

$\nabla$

Nach mehrjähriger Vorarbeit seit 2008 wurde Anfang 2012 der Nationale Krebsplan veröffentlicht [1] und eine Gesetzgebung zur Umsetzung auf den Weg gebracht [2]. Beide betreffen auch die Früherkennung des Zervixkarzinoms. Die Früherkennung auf ein Zervixkarzinom ist bereits seit vielen Jahren Bestandteil einer Krebsfrüherkennungs-Richtlinie [3] (basierend auf der Fassung des Bundesausschusses der Ärzte und Krankenkassen vom 01.07.1971). Nun soll das in Deutschland etablierte Verfahren [4] in Orientierung an der Europäischen Leitlinie [5] weiterentwickelt werden. Ziel dieser Neuorganisation ist eine weitere Senkung der Inzidenz und Mortalität des Zervixkarzinoms in Deutschland bei Minimierung der Risiken und Optimierung des Nutzens des Verfahrens - so das Anliegen, das im Gesetz zur Weiterentwicklung der Krebsfrüherkennung und zur Qualitätssicherung durch klinische Krebsregister (Krebsfrüherkennungs- und -registergesetz - KFRG) Niederschlag findet [6]. Der Deutsche Bundestag hat am 31.01.2013 das Gesetz zur Weiterentwicklung der Krebsfrüherkennung und zur Qualitätssicherung durch klinische Krebsregister (Krebsfrüherkennungs- und -registergesetz) beschlossen [7] und es ist am 10.04.2013 in Kraft getreten.

Welche Änderungen dafür notwendig sein werden, soll letztlich in einem entsprechenden Verfahren des Gemeinsamen Bundesausschusses erarbeitet und festgelegt werden. Die Regelungen schaffen einen rechtlichen Rahmen und eine klare Aufgabenzuweisung für den Gemeinsamen Bundesausschuss, der für die inhaltliche und organisatorische Ausgestaltung der Krebsfrüherkennung in seinen Richtlinien zuständig ist. Der Gemeinsame Bundesausschuss und die gemeinsame Selbstverwaltung werden verpflichtet, die bestehende Früherkennungsuntersuchung für ein Zervixkarzinom in ein organisiertes Krebsfrüherkennungsprogramm zu überführen.

Die Vorstellungen dazu sind sehr unterschiedlich, auch innerhalb des Fachgebiets der Frauenheilkunde [8-10]. Nur eine sachlich begründete und evidenzbasierte Road Map kann den Weg weisen [11,12].

Diesen Ansatz skizziert auch ausdrücklich der Entwurf des Gesetzes zur Weiterentwicklung der Krebsfrüherkennung und zur Qualitätssicherung durch klinische Krebsregister: Der Gemeinsame Bundesschuss hat bei der näheren Ausgestaltung der organisierten Krebsfrüherkennungsprogramme die Empfehlungen der entsprechenden Europäischen Leitlinien angemessen zu berücksichtigen. Bei den Europäischen Leitlinien handelt es sich - wie bei medizinischen Leitlinien generell - nicht um starre und streng verbindliche Vorgaben, sondern um wissenschaftliche und fachliche Orientierungshilfen im Sinne von „Handlungs- und Entscheidungskorridoren“, von denen der Gemeinsame Bundesausschuss in fachlich nachvollziehbar begründeten Fällen abweichen kann. Die Europäischen Leitlinien sind ohnehin so formuliert, dass sie den einzelnen Mitgliedstaaten sinnvolle Beurteilungsspielräume bei der nationalen Ausgestaltung ihrer Krebsfrüherkennungsprogramme lassen. Damit bleibt grundsätzlich Handlungsraum für nationale Empfehlungen und Leitlinien. Allerdings hat bei der Ausgestaltung der organisierten Krebsfrüherkennungsprogramme der Gemeinsame Bundesausschuss den jeweils gültigen Stand des medizinischen Wissens zu berücksichtigen, der damit handlungsleitenden Charakter erhält. Hierzu gehören außer den Europäischen Leitlinien auch weitere, qualitativ hochwertige und evidenzbasierte nationale und internationale Leitlinien sowie Studien. Damit ist die Adaptation an die deutschen Rahmenbedingungen und die Einarbeitung des aktuellsten Erkenntnisstands ausdrücklich bei der Umgestaltung des Verfahrens zur Früherkennung des Zervixkarzinoms vorgesehen. Das bedeutet, dass für unterschiedliche Vorgehensweisen und neue Entwicklungen, wie beispielsweise die Verfügbarkeit der HPV-Impfung (Impfung gegen HPV [humane Papillo- 
2007 by the German Standing Committee on Vaccination Recommendations [STIKO] and included in the vaccination plan), their influence on and the benefit for the establishment of an organized early detection concept to be determined specifically. This also holds for consideration of the guidelines at the S3 level currently under development (announced 13.08.2012) for the new evaluation of cervical cancer prevention with special attention to HPV detection in the framework of prevention and clarification of suspicious findings [13] or the upgrade of the S2 guidelines "cervical cancer" with focus on diagnostics, therapy and aftercare of patients with cervical cancer (registered 01.02.2011).

If the Federal Joint Committee decides that the medical benefit of a new method for early detection is as such not sufficiently validated, further testing is possible and scheduled (option according to $\S 137$ e SGB V). If it should appear reasonable and necessary, the FJC can also combine the testing of a cancer early detection method with regard to medical benefit with the testing of design elements of an organised cancer early detection programme. The legal framework explicitly allows for a prolongation of the time period for the preparation, performance and evaluation of the tests by the Federal Joint Committee for regulation of an organised cancer screening programme.

The reports published at the beginning of the year by IQWIG and the American Agency for Healthcare Research and Quality (AHRQ, USA) are concerned with early detection of cervical cancer and, besides the utility of the HPV test, also address other elements in screening procedures. Both provide preparatory work $[14,15]$. In many aspects the reports come to similar results. Even so the introduction in Germany - as for every other complex intervention in a health care system - requires implementation adapted to the prevailing situation in the country, under step and stage-wise clarification or, respectively, scientific evaluation according to the objectives laid down [16].

The numerous different approaches, based on the recommendations of the European Union of $2003^{1}$ that can be encountered in European countries not least due to their limited comparability and the wide variety of their results ( $\bullet$ Table 1 ), demonstrate the importance of the search for a procedure properly fitting for German conditions.

In light of the demographic developments in population and the increasing risk of cancer with increasing age, a coordinated, target-oriented procedure of all actors involved in the fight against cancer is absolutely essential (BMG, "research in national cancer plan").

\section{Changes Should be Based on Evidence and Results of Exemplary Projects $\nabla$}

The European guidelines themselves as well as the national cancer plan and the cancer plan implementation law explicitly state that changes should previously be examined in models and research to what extent they correspond to the objectives of a procedural change. At first an exemplary testing in the framework of a regional and time-limited procedure is explicitly recommended prior to a nationwide introduction of organised screening programmes. [27]. This should provide valuable information for a later nationwide

\footnotetext{
${ }^{1}$ Commission of European Community. Suggestion for a recommendation of the council on the rate of cancer care. 2003/0093 (CNS). URL: http://eurlex.europa.eu/LexUriServ/LexUriServ.do?uri=COM:2003:0230:FIN:DE:PDF
}

maviren] wurde in Deutschland 2007 von der ständigen Impfkommission [STIKO] empfohlen und in den Impfplan aufgenommen), Auswirkungen auf und Stellenwert für die Etablierung eines organisierten Screenings konkret zu bestimmen sind. Dies gilt auch für die Berücksichtigung der derzeit in Entwicklung befindlichen Leitlinie (Anmeldung 13.08.2012) zur Neubewertung der Zervixkarzinomprävention auf S3-Niveau unter besonderer Berücksichtigung des HPV-Nachweises im Rahmen der Vorsorge und der Abklärung auffälliger Befunde [13] oder das Upgrade der S2-Leitlinie „Zervixkarzinom“ mit Fokus auf Diagnostik, Therapie und Nachsorge der Patientin mit Zervixkarzinom (angemeldet 01.02.2011).

Stellt der Gemeinsame Bundesausschuss fest, dass der medizinische Nutzen einer neuen Früherkennungsmethode als solcher noch nicht hinreichend belegt ist, ist weitere Erprobung möglich und vorgesehen (Option nach $§ 137$ e SGB V). Wenn es sinnvoll und erforderlich erscheint, kann der G-BA die Erprobung hinsichtlich des medizinischen Nutzens einer Krebsfrüherkennungsmethode auch mit der $\mathrm{Er}$ probung von Ausgestaltungselementen eines organisierten Krebsfrüherkennungsprogramms verbinden. Der gesetzliche Rahmen sieht ausdrücklich eine Verlängerung der für den Gemeinsamen Bundesausschuss vorgesehenen Fristen zur Regelung der organisierten Krebsfrüherkennungsprogramme um den Zeitraum der Vorbereitung, Durchführung und Auswertung der Erprobung vor.

Die Anfang des Jahres veröffentlichten Berichte des IQWIG und der US-amerikanischen Agency for Healthcare Research and Quality (AHRQ USA), die sich mit der Früherkennung bei Zervixkarzinom befassen und neben dem Stellenwert des HPV-Tests auch andere Elemente in einem Screening-Verfahren aufgegriffen haben, haben ihrerseits Vorarbeiten geleistet [14,15]. Zu zahlreichen Aspekten kommen die Berichte zu ähnlichen Ergebnissen. Dennoch bedarf die Einführung in Deutschland - wie jede andere komplexe Intervention in ein Gesundheitsversorgungssystem - der auf die Situation des Landes zugeschnittenen Umsetzung, unter schritt- und stufenweiser Klärung bzw. wissenschaftlicher Bewertung anhand der vorgegebenen Ziele [16].

Die Vielfalt unterschiedlicher Ausgestaltungen, die auf Basis der Empfehlung der Europäischen Union von $2003^{1}$ in den europäischen Ländern anzutreffen sind, verdeutlichen nicht zuletzt wegen ihrer nur eingeschränkten Vergleichbarkeit und großen Unterschiedlichkeit der Ergebnisse ( $\bullet$ Tab.1) die Bedeutung der Suche nach einer für Deutschland passgerechten Vorgehensweise.

Angesichts der demografischen Entwicklung der Bevölkerung und des steigenden Risikos einer Krebserkrankung mit zunehmendem Alter ist ein aufeinander abgestimmtes, zielorientiertes Vorgehen aller an der Krebsbekämpfung beteiligten Akteure unbedingt erforderlich (BMG, „Forschung im Nationalen Krebsplan“).

\section{Änderungen sollen in Evidenz und durch Ergebnisse von Modellvorhaben begründet sein \\ $\nabla$}

Die Europäische Leitlinie selbst, wie auch der Nationale Krebsplan und das Krebsplanumsetzungsgesetz, halten fest, dass Änderungen zuvor in Modellen und Forschung daraufhin zu untersuchen sind, inwieweit sie der Zielsetzung einer Verfahrensänderung entsprechen. Ausdrücklich wird vor der flächendeckenden Einführung organisierter Screening-Programme zunächst die modellhafte Erprobung im Rahmen

\footnotetext{
${ }^{1}$ Kommission der Europäischen Gemeinschaften. Vorschlag für eine Empfehlung des Rates zur Krebsvorsorge. 2003/0093 (CNS). URL: http://eurlex.europa.eu/LexUriServ/LexUriServ.do?uri=COM:2003:0230:FIN:DE:PDF
} 
离离

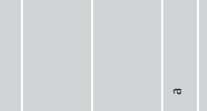

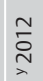

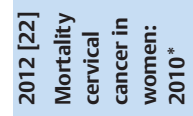

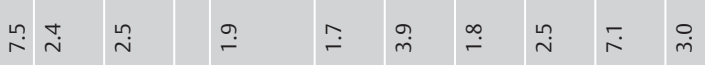

$\bar{i} \quad \stackrel{+}{+}$

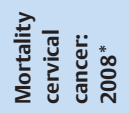

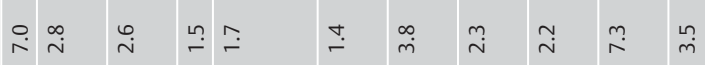

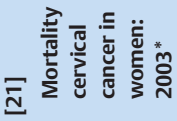

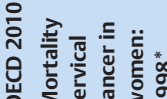

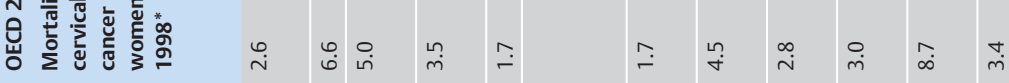

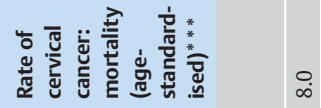

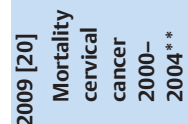

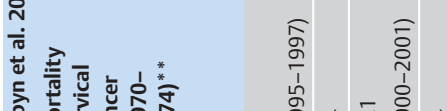

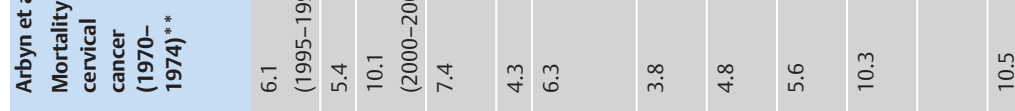

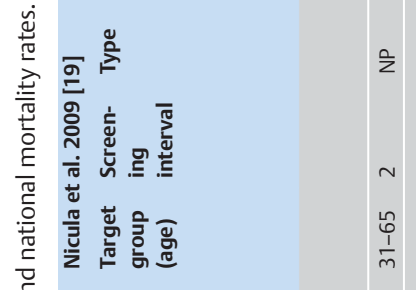

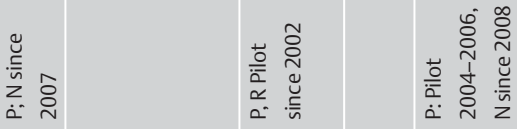

$\bar{i} \quad \stackrel{\leftrightarrow}{*}$

$\stackrel{\circ}{i}$

$\Phi$

商蒙言惫

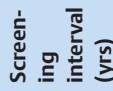

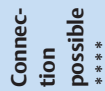

$\stackrel{\infty}{\sim}$

$x^{2}$

뇬

กำ

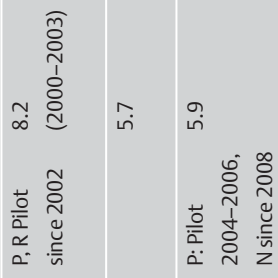

$\stackrel{\leftrightarrow}{\sim}$

นึ.

m

$\stackrel{ก}{ก}$

Int

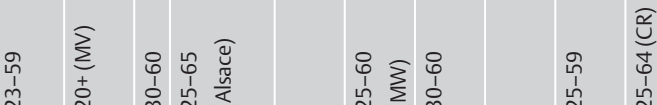

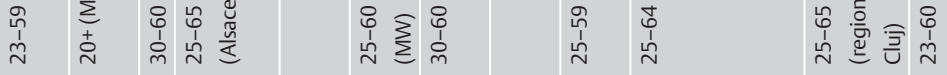

苍苞苞

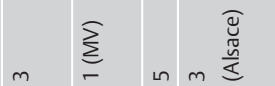

$\sum_{\text {in }}^{\infty}$

亭

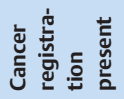

离密密

$\stackrel{\varrho}{\searrow}$

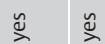

$m \frac{\widetilde{s}}{m}$

$\mathfrak{0}$
0
$\vdots$
$\omega$

0
$\dot{0}$
$\stackrel{1}{N}$

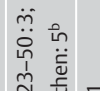

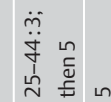

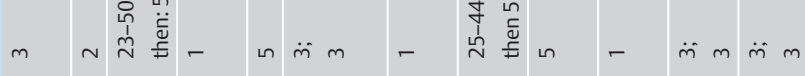

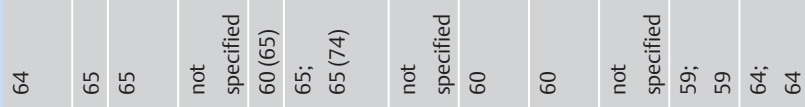

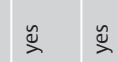

๗

至

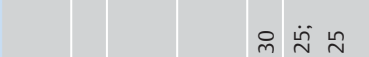

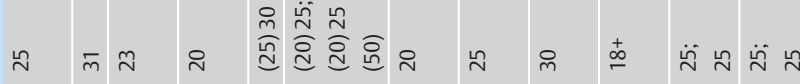

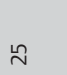

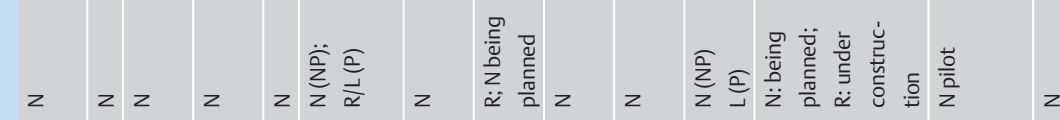

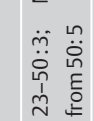

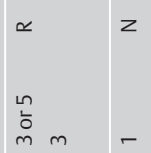

會能导

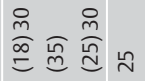

至

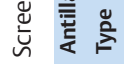

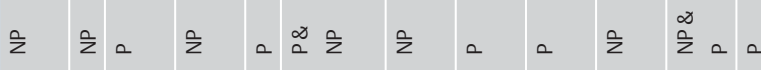

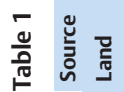

I II

i

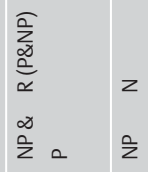

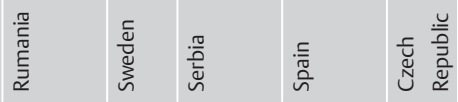




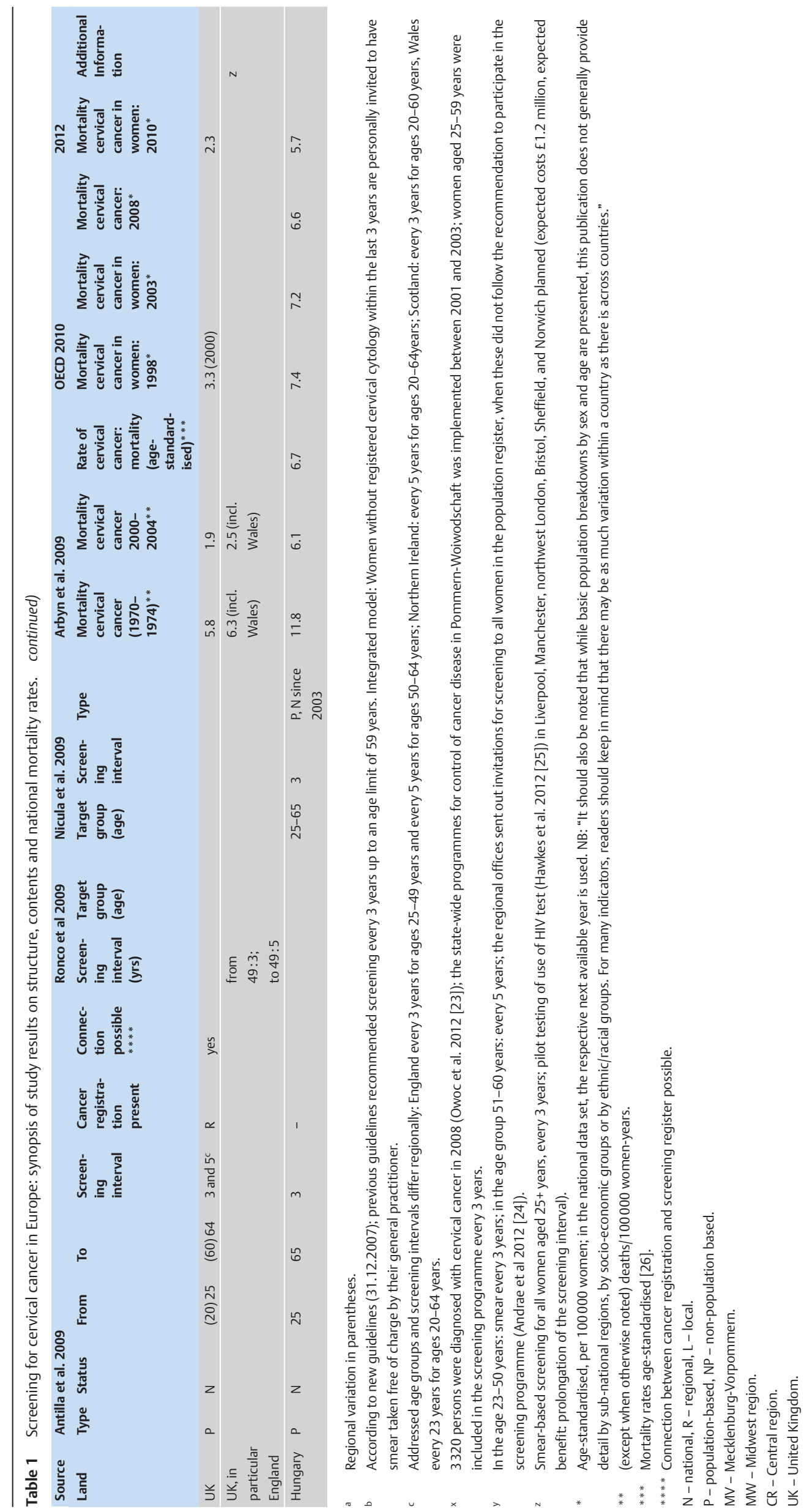


implementation. If and with what scope a test regulation should be applied must be determined by the Federal Joint Committee in a directive.

The background for this approach is the statutory regulation that details of the proposed procedure, such as for example, age limit or methodological process as well as the frequency of utilisation should in future not be governed by the legislature but be determined by the Federal Joint Committee. The latter should flexibly adapt the examination to the current state of medical knowledge, which is to be verified within the framework of the respective procedure. The draft law only specifies obligatory components and minimum components of an organised cancer screening programme.

A changed screening concept must finally be evaluated by the extent to which it can, oriented on the recommendations of the European guidelines, realise a reduction of disease burden (mortality/ incidence) and damage potential (false-positive findings, over diagnostics, over therapy, creation of a false sense of security due to false-negative findings) as well as a cost-effective management under German circumstances. The disease burden includes, besides cervical cancer, also its precursor stages and consequences. This gives rise to two important areas of activity for the medical field: definition of the research fields and cooperation in differing models - with participation of all sectors. The new knowledge thus gained can then be used in the working groups of the Federal Joint Committee and a consensus process, and possibly also enables conclusions to be drawn in respective of the development of new guidelines (see below). Also the Federal Ministry of Health emphasises with its funding initiatives for the national cancer plan that numerous questions are still unanswered and thus do not allow a direct synthesis to a new directive for early detection.

\section{What Topics are Still Open?}

$\nabla$

A population-related and quality-assured screening for cervical cancer should be implemented in an organised process. In the European guidelines elements are named that characterise a population-related, organised screening; these include exact procedural requirements, defined structures, an organisation team (e.g., regional) to support screening and a procedure to determine the burden of disease in the population ${ }^{2}$.

Oriented on these criteria for an organised screening, changes are needed at the following positions in comparison to the current early detection scheme:

- Invitation procedures (to date not established on a population basis)

- Comprehensive information (as yet not centrally regulated)

- Evaluation of individual procedural steps, also methodological, in comparison with the recommendations of the European guidelines: where are unified procedural rules needed (and which ones)?

\footnotetext{
2 "Organised screening programmes require a specific screening policy (specifying targeted population groups and the screening test, intervals and other procedures) and a team at the national or regional level responsible for implementing the policy, i.e., for organising the supply of the screening services, maintaining the requisite quality, and reporting on performance and results. In addition, a quality-assurance structure is required and a means of ascertaining the population burden of the disease should be available. Population-based screening programmes generally require a high degree of organisation."
}

regional und zeitlich begrenzter Vorhaben empfohlen. [27] Hieraus sollen wichtige Erkenntnisse für eine spätere bundesweite Umsetzung gewonnen werden. Ob und welche Anteile einer Erprobungsregelung zugeführt werden sollen, soll der Gemeinsame Bundesausschuss in einer Richtlinie bestimmen.

Hintergrund dieses Ansatzes ist die gesetzliche Regelung, dass inhaltliche Einzelheiten des zukünftigen Verfahrens, wie beispielsweise Altersuntergrenzen oder methodisches Vorgehen sowie die Häufigkeit der Inanspruchnahme von Krebsfrüherkennungsuntersuchungen, künftig nicht mehr durch den Gesetzgeber, sondern durch den Gemeinsamen Bundesausschuss festgelegt werden. Dieser soll flexibel die jeweilige Untersuchung an den aktuellen Stand des medizinischen Wissens anpassen, welcher also im Rahmen des Verfahrens jeweils konkret festzustellen sein wird. Der Gesetzentwurf gibt lediglich obligate Bestandteile und Mindestanforderungen an organisierte Krebsfrüherkennungsprogramme vor.

Eine geänderte Screening-Konzeption muss sich letztendlich daran messen lassen, inwieweit, orientiert an den Empfehlungen der Europäischen Leitlinie, eine Senkung der Krankheitslast (Mortalität/Inzidenz) und des Schadenspotenzials (falsch positive Befunde, Überdiagnostik, Übertherapie, Vermittlung einer falschen Sicherheit durch falsch negative Befunde) sowie eine kosteneffektivere Versorgung unter deutschen Rahmenbedingungen erreicht werden kann. In die Krankheitslast gehen neben dem Zervixkarzinom auch seine Vorstufen und die Konsequenzen ein.

Daraus ergeben sich 2 wichtige Handlungsfelder für das Fachgebiet: Definieren der Forschungsbereiche und Mitarbeit an unterschiedlichen Modellen - unter Beteiligung aller Sektoren. Aus der dann gewonnenen neuen Erkenntnislage können für die Gremienarbeit im Gemeinsamen Bundesausschuss und einen Konsensprozess, ggf. auch die Entwicklung einer neuen Leitlinie (s.u.), Schlüsse gezogen werden. Auch das Bundesministerium für Gesundheit macht mit seiner Förderinitiative zum Nationalen Krebsplan deutlich, dass zahlreiche Fragen offen sind, die noch keine unmittelbare Synthese zu einer neuen Krebsfrüherkennungsrichtlinie erlauben.

\section{Welche Themenfelder sind offen? \\ $\nabla$}

Ein bevölkerungsbezogenes, qualitätsgesichertes ZervixkarzinomScreening soll in einem organisierten Verfahren implementiert werden. In Europäischen Leitlinien werden Elemente benannt, die ein bevölkerungsbezogen organisiertes Screening charakterisieren; dazu zählen: genaue Verfahrensvorschrift, definierte Strukturen, ein das Screening unterstützendes Organisationsteam (z.B. regional) und ein Verfahren zur Bestimmung der Krankheitslast in der Bevölkerung². Orientiert an diesen Kriterien eines organisierten Screenings ergibt sich im Vergleich zu den Vorgaben der bestehenden Früherkennungsrichtlinie Änderungsbedarf an folgenden Stellen:

- Einladungsverfahren (bisher nicht bevölkerungsbezogen eingerichtet)

- umfassende Information (bisher nicht zentral geregelt)

2 "Organised screening programmes require a specific screening policy (specifying targeted population groups and the screening test, intervals and other procedures) and a team at the national or regional level responsible for implementing the policy, i.e. for organizing the delivery of the screening services, maintaining requisite quality, and reporting on performance and results. In addition, a quality-assurance structure is required and a means of ascertaining the population burden of the disease should be available. Population-based screening programmes generally require a high degree of organisation." 
- Revision of the quality concept

- Quality transparency

- Finally: summary in an organisational concept (screening policy)

An organised cervical cancer screening is considered to be a multi-stage process with a sequence of interlocking specific process steps. The success of the sequential steps is thereby also dependent on their appropriateness (in concept, organisation and performance of the preceding step). This directs attention to, for example, the problem of over therapy for CIN as well as to the field of under treatment: none of the six relevant studies upon which were based the conclusions of the IQWIG final report "Assessment of benefit of an HPV test in primary screening of cervical cancer" provided "usable data on the patient-relevant endpoints overall survival, disease-specific mortality, undesired consequences of the screening strategy and changes in health-related quality of life. In the studies included in this assessment of benefit, even mediumgrade dysplasias (CIN 2) were treated (in one study even lowgrade dysplasias). In most cases CIN 2 regresses and only very rarely develops into an invasive cervical cancer. Thus, in very many cases treatment constitutes an over therapy" [14]). For example, if particular population groups are systematically inadequately included and thus experience under treatment, this has an impact on the total results of a population-based screening independently of the quality of the performance or evaluation of the swab specimens.

The elaboration process, carried out mainly under the guidance of the FJC and in the framework of committee work associated with the FJC, is intended to check in particular which elements require further development and to what extent as well as to determine which can be retained on the basis of proven value [28]. Cost effectiveness and system compatibility are also equally important test features with regard to inclusion of existing structures [11].

It is all about a targeted organisational further development and, in part, new organisation of the already established cervical cancer early detection scheme, into which the elements of an organised screening are to be incorporated - however, strictly in accord with the objective: maximise benefit, minimise risks.

Since the FJC is the central agency, control of the process lies mainly with the competence of the self-governing bodies working together within the FJC: National Association of Statutory Health Insurance Physicians, German Hospital Federation and the Statutory Health Insurance. The procedure thereby follows the public and consensus rules of the FJC for the creation of directives, e.g., also with regard to transparency of the process, the consideration of different levels of evidence, and the advice of institutions and groups called upon for consulation (e.g., German Nursing Council, patient representatives).

- Fig. 1 shows an orienting workflow scheme for the process of early detection along which the fields of central open questions and topics of discussion, without any claims to completeness, are indicated. If, at a first glance, some fields already appear to include final solutions, a closer look reveals that many still open questions are included which require further research work from which guiding results will emerge [29]. Possible contents of the fields of action ( Table 2 ) are outlined below.
- Bewertung der einzelnen Verfahrensschritte, auch methodisch, im Abgleich mit Empfehlungen der Europäischen Leitlinie: wo werden vereinheitliche Verfahrensvorschriften (und welche) benötigt?

- Überarbeitung des Qualitätskonzepts

- Qualitätstransparenz

- schließlich: Zusammenfassung in einem Organisationskonzept („Screening Policy“)

Ein organisiertes Zervixkarzinom-Screening wird als mehrstufiger Prozess mit einer Abfolge von aufeinander aufbauenden Prozessschritten betrachtet. Der Erfolg der nachfolgenden Schritte ist dabei auch abhängig von der Angemessenheit (in Konzept, Organisation und Durchführung) des/der vorausgehenden. Dies richtet den Blick z. B. auf die Problematik von Übertherapie bei CIN ebenso wie auf Bereiche von Unterversorgung: Keine der für die Schlussfolgerungen des IQWIGAbschluss-Berichts „Nutzenbewertung eines HPV-Tests im Primärscreening des Zervixkarzinoms“ 6 relevanten Studien lieferte „auswertbare Daten zu den patientenrelevanten Endpunkten Gesamtüberleben, krankheitsspezifische Mortalität, unerwünschte Folgen der Screening-Strategie und Veränderung der gesundheitsbezogenen Lebensqualität. In den in diese Nutzenbewertung eingeschlossenen Studien wurden bereits mittelgradige Dyplasien (CIN 2) therapiert (in einer Studie sogar bereits niedriggradige Dysplasien). CIN 2 bilden sich in den meisten Fällen zurück und entwickeln sich nur selten zu invasiven Zervixkarzinomen weiter. Die Behandlung bedeutet deshalb in sehr vielen Fällen eine Übertherapie“ [14]). Werden bestimmte Bevölkerungsgruppen beispielsweise systematisch mangelhaft erreicht und damit eine Unterversorgung hervorgerufen, beeinträchtigt diese das Gesamtergebnis des bevölkerungsbezogenen Screenings unabhängig von der Qualität der Durchführung oder Bewertung der Abstriche. Der Prozess der Erarbeitung, der im Wesentlichen unter Führung des G-BA und im Rahmen der G-BA-gebundenen Gremienarbeit erfolgen wird, hat insbesondere zu prüfen, welche Elemente der Weiterentwicklung bedürfen, in welchem Umfang und inwieweit als bewährt Erfahrenes [28] beibehalten werden kann. Kosteneffektivität und Systemkompatibilität legen die Prüfung des geeigneten Einbezugs vorhandener Strukturen gleichermaßen nahe [11].

Es geht um eine gezielte organisatorische Weiterentwicklung und teilweise Neuorganisation der bereits etablierten Zervixkarzinom-Früherkennung, bei der die Elemente eines organisierten Screenings eingearbeitet werden - allerdings konkret entlang der strengen Richtschnur der Zielsetzung: Nutzen maximieren, Risiken minimieren.

Da als zentral Handelnder der G-BA vorgesehen ist, liegt die Steuerung des Prozesses wesentlich in der Kompetenz der im G-BA zusammenwirkenden Selbstverwaltungspartner: Kassenärztliche Bundesvereinigung, Deutsche Krankenhausgesellschaft und die Gesetzliche Krankenversicherung. Das Vorgehen folgt dabei der öffentlichen und konsentierten Verfahrensordnung des G-BA zur Erstellung von Richtlinien, z.B. auch hinsichtlich der Verfahrenstransparenz, des Umgangs mit Evidenz unterschiedlicher Güte und beratend einbezogener Institution und Gruppen (z. B. Deutscher Pflegerat, Patientinnenvertreter/innen).

- Abb. 1 zeigt eine orientierende Ablaufskizze für den Prozess der Früherkennung, entlang derer zentrale offene Fragen und Diskussionsbereiche, ohne Anspruch auf Vollständigkeit, gekennzeichnet sind. Wenngleich auf den ersten Blick manche Bereiche schon eine eindeutige Lösung zu beinhalten scheinen, erweist sich bei näherem Hinsehen, dass darin eine Vielzahl von noch zu klärenden Fragen enthalten ist, die konsequenter forschender Bearbeitung bedürfen, aus der dann handlungsleitende Ergebnisse hervorgehen [29]. Mögliche Inhalte der Handlungsfelder ( Tab. 2) werden dahingehend im Folgenden skizziert. 


\section{Process step}

\section{Advertising}

Motivation interview

Invitation within the organised screening process

Gynaecological early detection examination, cervical smear taking in curative setting

Early detection cervical cancer (screening) - cervical smear test

\section{Further procedure for} unremarkable findings

Further procedure for suspicious findings: control

Process of clarification for still suspicious findings (e.g., differential coloscopy ${ }^{* * *}$, conisation)

Further measures for cervical cancer

Surveillance

Monitoring/evaluation
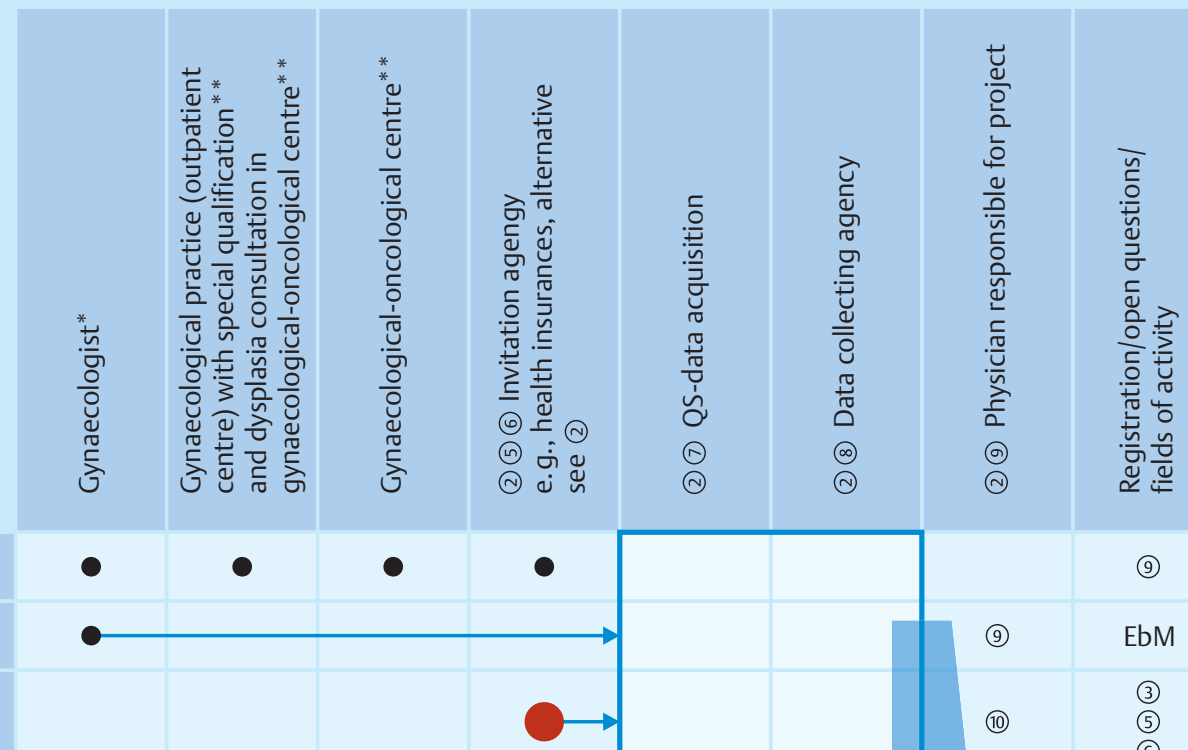

(9)

(9)

EbM

(10)

(3)

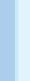
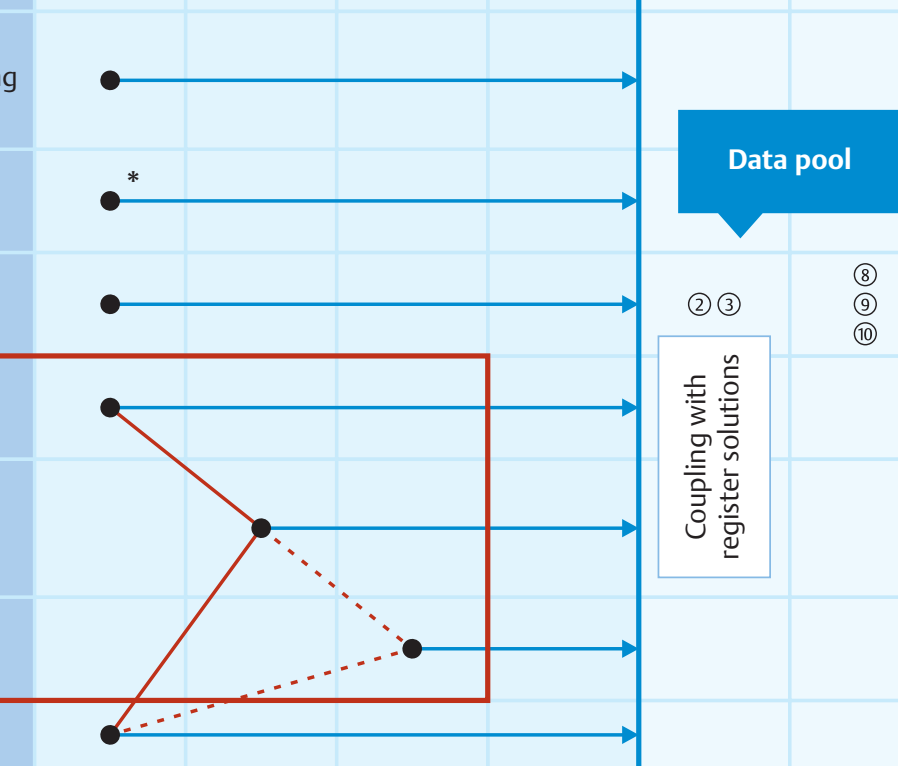

(3) (4)

* On participation in screening procedure registered by physician responsible for project, subject to requirements of sector-equal quality assurance according to $\S 137$ a SGB V.

** Qualification according to the requirements of certification or, respecticely, accreditation specifications in the framework of the new FJC guidelines for special task in the course of the screening procedure as well as from sector-equal quality assurance.

*** AQUA Institute, closing report conisation, 2008 (Differential colposcopy with biopsy is the gold standard procedure for the minimally invasive histological clarification in primary screening examinations and for therapy planning in case of histologically confirmed neoplasms. The objective of differential colposcopy is to obtain histological findings. It includes inspection, acetate testing and biopsy.)

- Performance/participation

(1) See overview and explanation of fields of activity (Table 1)

- Data flow

— Route for patient with suspicious findings

Fig. 1 Roadmap and survey of the fields of action. 
Table 2 Survey of the fields of action.

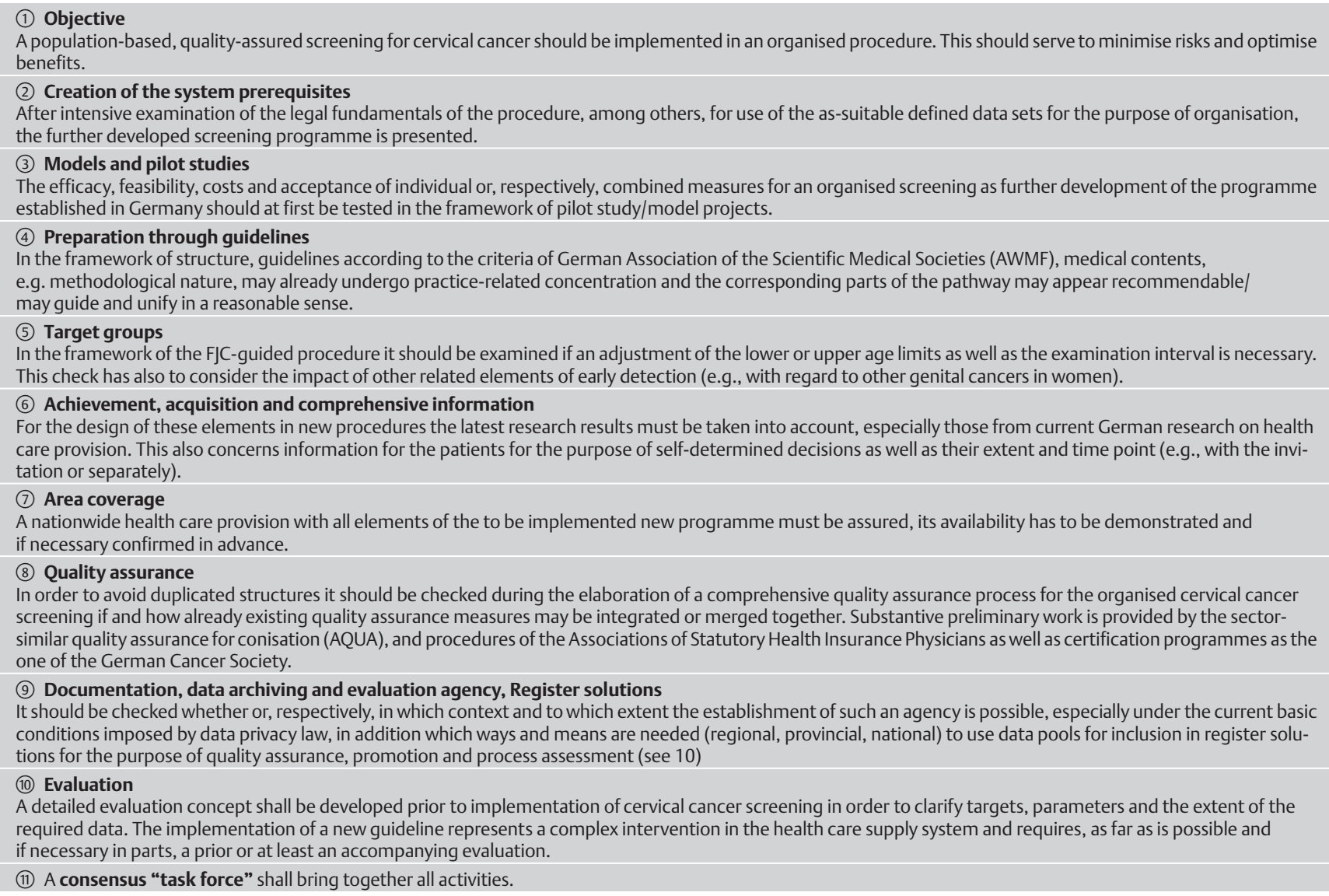

\section{What do the Fields of Action Contain? \\ $\nabla$}

\section{(1) Consensus with regard to targets}

The creation of a mutual understanding of the objectives is a prerequisite for target-oriented activities in all the fields of action listed below. The national cancer plan and implementation laws equally at the beginning of the discussion on the further development of a national procedure - in accord with the European guidelines - stress the fact in their formulation that also population-medical reasonable and recommendable cancer screening measures involve risks for healthy and complaint-free persons. These include - besides the risk of the examination itself - the consequences of false-negative or false-positive test findings, invasive methods of clarification (e.g., taking tissue samples, therapy for early stages) as well as the possible diagnosis and treatment of a cancer disease of which in the absence of cancer screening the subjects would never have noticed during their lifetimes. Such risks cannot always be avoided even by the best possible quality assurance but can at most be minimised. Thus emphasis is placed on the search for the best possible further development of the national procedure, on the detailed definition of risks in all directions, and simultaneously on information ("informed participation") and involvement of the patients concerned (strengthening patient orientation).

\section{Was beinhalten die Handlungsfelder?}

\section{(1) Konsentierung der Zielsetzung}

Die Herstellung eines gemeinsamen Verständnisses zur Zielsetzung ist die Voraussetzung eines zielgerichteten Handelns in allen nachstehend aufgeführten Handlungsfeldern. Nationaler Krebsplan und Umsetzungsgesetz gleichermaßen heben zu Beginn der Diskussion um eine Weiterentwicklung des nationalen Verfahrens - in Einklang mit den Europäischen Leitlinien - in ihren Formulierungen darauf ab, dass auch bevölkerungsmedizinisch sinnvolle und empfehlenswerte Krebsfrüherkennungsmaßnahmen für die gesunde bzw. beschwerdefreie Person ein Risiko beinhalten. Hierzu gehören - neben den Risiken der Untersuchung selbst - die Konsequenzen falsch negativer oder falsch positiver Testbefunde, invasive Abklärungsuntersuchungen (z.B. die Entnahme von Gewebeproben, Therapie der Vorstufen) sowie die mögliche Diagnose und Behandlung von Krebserkrankungen, von denen die Person ohne die Früherkennung in ihrem Leben nie etwas gemerkt hätte. Solche Risiken lassen sich auch durch die bestmögliche Qualitätssicherung nicht in allen Fällen vermeiden, sondern allenfalls minimieren. Daher liegen Schwerpunkte bei der Suche nach der besten Weiterentwicklung des nationalen Verfahrens auf der detaillierten Definition von Risiken in jeglicher Richtung und gleichzeitig auf der Information (,informierten Teilnahme“) und Einbeziehung der Betroffenen (Stärkung der Patientenorientierung). 


\section{(2) Creation of the system prerequisites}

The establishment of an organised screening procedure places high demands on data planning, data flow and the fitting accuracy with regard to national data protection regulations.

Thus, at first the minimum requirement for data is to be defined, the required data minimisation and the avoidance of multiple requests for data have to be taken into account and targets and purposes have to be oriented on the aims of the new organisation. Correspondingly, specifications for a uniform data acquisition are given as central statements in appendix 2 of information on the law for further development of cancer screening and on quality assurance through clinical cancer registers (KFRG) - regulatory section "clinical cancer register" [30]. The draft law proposes the establishment of clinical cancer registers by the federal states. In order to simplify the work on clinical cancer registers the draft includes a catalogue of clearly defined tasks that the clinical cancer registers have to fulfil. Particularly important for the nationwide use of cancer registers is the uniform compilation of data. "A data set elaborated by medical experts for the documentation of patients suffering from cancer provides the foundation for a clinical cancer register.

Only after extensive testing should/can the legal foundations for the procedures be drafted, among others, for use as a suitably defined data set for the purpose of organisation of the further developed early detection programme. The differing options for the data bases for inivitation procedures, for follow-up, quality assurance, monitoring and evaluation must first be checked for availability, reliability of use and suitability. For example, for invitation procedures census records/insurants' data/patient records from practices and facilities (call/re-call) may be considered. In the international review (good) experience with widely differing options is recorded. In the framework of the FJC and its subcommittees, e.g., subcommittee quality assurance, a comparative view of already formulated regulations for other fields can be undertaken so that evaluated experience from national and international models as well as the latest research results can be taken into consideration. The elaboration of the necessary regulations can be checked in parallel to their compatibility with data protection in Germany.

\section{(3) Models and pilot studies}

The efficacy, feasibility, costs and acceptance of individual or, respectively, combined measures for an organised screening in the further development of the programme already established in Germany, as determined by the FJC, should at first be examined in pilot studies/model projects. Pilot studies/model projects with scientific support are also necessary for, among others, the creation of an invitation procedure, a monitoring system or a fail-safe system to ensure the clarification of conspicuous findings. Further fields for research are methodological steps and their compatibility with the German legal situation (also for data protection), the inclusion of vulnerable population groups, the nationwide coverage of services, cost efficiency, etc.

When different facilities (clinics, research institutions) of the specialty participate in the research projects it may be possible within the German Society for Gynaecology and Obstetrics (DGGG) to hold a ballot on prioritisation and make contributions to the clarification of certain issues.

\section{(4) Preparation through guidelines}

The development of guidelines can also be included in the preparation of the new procedure: guidelines can provide support in

\section{(2) Schaffung der Systemvoraussetzungen}

Die Etablierung eines organisierten Screening-Verfahrens stellt hohe Anforderungen an die Datenplanung, den Datenfluss und die Passgenauigkeit zu den nationalen Datenschutzbestimmungen.

Daher ist zunächst der Mindestbedarf an Daten zu definieren, die gebotene Datensparsamkeit und Vermeidung von Mehrfacherhebungen zu berücksichtigen und Ziel und Zwecke der Nutzung am Ziel der Neuorganisation zu orientieren. Entsprechend finden sich Festlegungen für eine einheitliche Datenerfassung in Anlage 2 Informationen zum Gesetz zur Weiterentwicklung der Krebsfrüherkennung und zur Qualitätssicherung durch klinische Krebsregister (KFRG) - Regelungsteil „Klinische Krebsregister“ [30] als zentrale Aussagen: Der Gesetzentwurf sieht die Einrichtung klinischer Krebsregister durch die Länder vor. Um die Arbeit der klinischen Krebsregister zu vereinheitlichen, enthält der Entwurf einen Katalog festgelegter Aufgaben, die klinische Krebsregister wahrzunehmen haben. Besonders wichtig für den bundesweiten Nutzen der Krebsregistrierung ist die einheitliche Erfassung der Daten. „Ein in medizinischen Fachkreisen erarbeiteter Datensatz für die Dokumentation von an Krebs erkrankten Menschen bildet die Grundlage für die klinische Krebsregistrierung."

Erst nach umfassender Prüfung sollten/können die gesetzlichen Grundlagen des Verfahrens, u.a. zur Nutzung des als geeignet definierten Datensatzes zum Zweck der Organisation des weiterentwickelten Früherkennungsprogramms, erstellt werden. Die unterschiedlichen Möglichkeiten zur Datenbasis für Einladungsverfahren, zu Follow-up, Qualitätssicherung, Monitoring, Evaluation müssen zunächst auf Verfügbarkeit, Zulässigkeit ihrer Nutzung und Eignung geprüft werden. Z. B. kommen für das Einladungsverfahren Einwohnermeldedaten/Versichertendaten/Patientendaten aus Praxen und Einrichtungen (call/re-call) in Betracht. In der internationalen Übersicht liegen mit ganz unterschiedlichen Ansätzen (gute) Erfahrungen vor. Im Rahmen des G-BA und seiner Gremien, z. B. Unterausschuss Qualitätssicherung, kann eine Zusammenschau bereits getroffener Regelungen aus anderen Bereichen vorgenommen werden, sodass bewertete Erfahrung aus nationalen und internationalen Modellen bei der Entscheidung berücksichtigt werden kann, ebenso wie neueste Forschungsergebnisse. Die erforderlichen Regelungen werden parallel zur Erarbeitung auf ihre Vereinbarkeit mit dem Datenschutz in Deutschland überprüft.

\section{(3) Modelle und Pilotstudien}

Die Effektivität, Machbarkeit, Kosten und Akzeptanz einzelner bzw. kombinierter Maßnahmen für ein organisiertes Screening in Weiterentwicklung des in Deutschland eingeführten Programms sollen, je nach Festlegung durch den G-BA, zunächst im Rahmen von Pilotstudien/Modellprojekten geprüft werden. Pilotstudien/Modellprojekte mit wissenschaftlicher Begleitung werden u.a. für die Erstellung eines Einladungsverfahrens, eines Monitorings oder eines Fail-SafeSystems zur Sicherstellung der Abklärung auffälliger Befunde gegebenenfalls benötigt. Weitere Forschungsfelder sind methodische Schritte und ihre Anschlussfähigkeit an deutsche gesetzliche Regelungen (auch zum Datenschutz), der Einbezug von vulnerablen Bevölkerungsgruppen, die Flächendeckung von Angeboten, die Kosteneffektivität u.a.

Wenn sich unterschiedliche Einrichtungen (Kliniken, Forschungsinstitute) des Fachgebiets an den Forschungsvorhaben beteiligen, könnte eventuell innerhalb der DGGG eine Abstimmung zur Priorisierung der und die Konkretisierung bestimmter Fragestellungen angestoßen werden. 
the structuring of the individual procedural steps and the associated quality assurance. High-value guidelines are highly relevant for the practice. Guidelines for important subsections of the entire process for the diagnosis of and therapy for women with conspicuous findings from gynaecological cancer screening are currently in preparation (see above). Good guidelines and proper use thereof can thus directly serve for a unification of the specific medical methodological process (e.g., guideline-oriented algorithms for clarification, 0 Fig. 1).

The development of new guidelines for screening can make use of the evidence gathered during preparation of the AWMF guidelines and use it for the entire guideline elaboration process. In addition within the course of this process results from the phase of further research, evaluation and model work-up can be included where necessary (according to KFRG and the code of procedure of the FJC).

\section{(5) Target groups}

Whether or not an adaptation of, e.g., the lower and upper age limits and of the examination interval is needed requires a concrete assessment in the context of the German health care system on account of the widely differing scientific results. This is a prerequisite for clarification and definition of the target group.

The investigation consists mainly of an examination and evaluation of the available evidence. In addition (besides engagement of IQWIG), initiation of working and expert groups in the context of the participating subcommittees of the FJC should be considered. Thus the self-governing bodies are incorporated cross-sectorially in the processing and shaping.

The scientific evidence for this question has up to now been evaluated non-uniformly. Above all, there are no international studies on the benefit/damage profile, which varies with the examination interval (see expert reports from IQWIG and AHRQ [2012]) - this is just in the range of topics that are centrally affected by the new target: optimisation of benefit and minimisation of risks

For measures allowed according to the law (e.g., also examination of the uterus and skin in the genital region), the current programme calls for yearly intervals. According to the demands of the European guidelines and the KFRG, changes need an examination of the evidence state, this also holds for different examination intervals. Effects of variations of the examination intervals need, according to the rules of health care research for complex interventions [16], to be examined in many respects, against the background of the German health care system, e.g., the impact on compliance, under and over treatment, as well as other connected elements within the existing system of early detection.

There is at present an appreciable need for research, development and evaluation of scientifically-based concepts with regard to risk-adapted cancer screening - this is reflected by the Ministry of Health in the justification of its support programme. The particular topic of risk-adapted screening has been incorporated and serves for a more exact determination of its possible future utility. A risk-adapted screening aims at the identification of people with a markedly elevated risk on the basis of specific risk factors and to reduce the disease incidence and mortality of this group by targeted cancer screening measures.

\section{(4) Vorbereitung durch Leitlinien}

Auch die Entwicklung von Leitlinien kann in die Vorbereitung des neuen Verfahrens eingehen: Leitlinien können bei der Ausgestaltung der einzelnen Verfahrensschritte und der darauf aufzubauenden Qualitätssicherung Unterstützung geben. Hochwertige Leitlinien sind für die Praxis von hoher Relevanz. Leitlinien zu wichtigen Teilbereichen des Gesamtprozesses zur Diagnostik und Therapie von Frauen mit auffälligen Befunden aus der gynäkologischen Krebsvorsorge sind in Arbeit (vgl. o.). Gute Leitlinien und sachgerechter Umgang damit können unmittelbar einer Vereinheitlichung des fachlich-methodischen Vorgehens dienen (z.B. leitlinienorientiert Algorithmus zur Abklärung, $\odot$ Abb. 1).

Die Entwicklung einer neuen Richtlinie für die Früherkennung kann auf die für die AWMF-Leitlinienerarbeitung zusammengetragene Evidenz zurückgreifen und diese in den Gesamtprozess der Richtlinienerstellung aufnehmen. Hinzu kommen im Rahmen dieses Prozesses nötigenfalls (gemäß KFRG und Verfahrensordnung des G-BA) Ergebnisse aus der Phase von weiterer Forschung, Bewertung und Modellevaluation.

\section{(5) Zielgruppe}

Ob eine Anpassung z.B. der unteren und oberen Altersgrenzen sowie des Untersuchungsintervalls erforderlich ist, steht angesichts divergierender wissenschaftlicher Erkenntnisse zur konkreten Prüfung für den Kontext des deutschen Versorgungssystems an. Dieser ist Voraussetzung für eine Konkretisierung und Definition der Zielgruppe. Die Prüfung beinhaltet wesentlich eine Untersuchung und Bewertung der verfügbaren Evidenz. Dazu kommt (neben der Beauftragung des IQWIG) die Initiierung von Arbeits- bzw. Expertengruppen im Kontext der beteiligten Unterausschüsse des G-BA in Betracht. Damit sind die Selbstverwaltungspartner sektorenübergreifend in die Aufarbeitung/Ausgestaltung einbezogen.

Die wissenschaftliche Evidenz zu diesen Fragen wird bislang uneinheitlich eingeschätzt. Insbesondere fehlen international Untersuchungen zum Nutzen/Schaden-Profil, das mit dem Untersuchungsintervall variiert, (vgl. Gutachten des IQWIG und der AHRQ [2012]) also eben in dem Themenfeld, das die neue Zielsetzung: Optimierung von Nutzen und Minimierung des Risikos, zentral berührt.

Das derzeitige Programm sieht für die Maßnahme nach gesetzlichem Umfang (z. B. auch Untersuchung des Uterus, der Haut in der Genitalregion) jährliche Intervalle vor. Änderungen erfordern nach dem Anspruch der Europäischen Leitlinien und des KFRG eine Prüfung zur Evidenzlage, das gilt auch für unterschiedliche Untersuchungsintervalle. Auswirkungen von Variationen des Untersuchungsintervalls sind nach den Regeln der Versorgungsforschung bei komplexen Interventionen [16] in vieler Hinsicht zu prüfen, vor dem Hintergrund des deutschen Versorgungssystems z. B. in ihrer Auswirkung auf Compliance, Unter- und Überversorgung, andere im Zusammenhang stehende Elemente der Früherkennung.

Ein erheblicher Bedarf an Erforschung, Entwicklung und Evaluation wissenschaftlich begründeter Konzepte besteht derzeit noch hinsichtlich einer risikoangepassten Krebsfrüherkennung, so das BMG in der Begründung seines Förderprogramms. In dieses wurde die spezielle Thematik einer risikoangepassten Früherkennung daher aufgenommen und dient einer näheren Bestimmung des möglichen zukünftigen Stellenwerts. Eine risikoangepasste Früherkennung zielt darauf ab, Personen mit einem deutlich erhöhten Risiko anhand bestimmter Risikofaktoren zu identifizieren und die Krankheitshäufigkeit und Sterblichkeit in dieser Gruppe durch gezielte Krebsfrüherkennungsmaßnahmen zu senken. 


\section{(6) Acquisition, utilisation and comprehensive} information

For the incorporation of these elements in new procedures, above all, results from current German health care research are of interest.

From the side of the legislature high demands are made: Invitations to organised procedures should be accompanied by information to explain to the invited person the benefits and risks or, respectively, advantages and disadvantages of the respective early detection measure in an adequately balanced way in simple language that is appropriate and barrier-free for the target group so that they can make an informed decision whether to participate or not to participate in the cancer early detection scheme. This information should contain explanations on the foreseen collection, processing and use of data as well as the data protection measures to be taken [2]. Also, since the population-medically reasonable and recommendable cancer screening methods also involve risks for healthy and complaint-free subjects, the acceptance behaviour of the individual person should be determined solely by an adequate, neutral and comprehensive information and consultation as well as by the individual values and preferences of each particular person. The target of an informed, individual decision is placed above the target of an as high as possible participation rate (cancer screening and registration law KFRG). Accordingly, the legal regulations ( $§ 62$ SGB V) which couple the provision of a reduced limit for additional payment (Belastungsgrenze) for chronically ill subjects to a regular participation in cancer early detection, do not apply any more.

Concerning information for the patient with the aim at a self-determined decision, the length and time of receipt are decisive factors according to the current state of knowledge. The empowerment for self-determined decisions thus lies, according to the fundamental principles of the Ottawa $\mathrm{Charta}^{3}$, but also explicitly according to field of action 4 (strengthening patient orientation) of the national cancer plan, in the medical field of activity and will thus place high demands on the formulation of health literacy within the new guidelines.

What effects does it have when, e.g., information about the procedure is sent with the invitation to participate or separate from it? Among researchers there are various differing opinions as to how invitation procedures, communication and comprehensive information should be structured in order to, on the one hand realise the participation of as many women as possible and on the other hand, to support free decision making (e.g. MARZY study, Mainz, study population: 5000 women aged from 30 to 65 years, living in the city of Mainz and the Mainz-Bingen region of Rheinland-Palatinate; sponsored by the Deutsche Krebshilfe $[31,32])$. The form of communication is, for example a module within the MARZY study.

In order to approach the ideal of nation-wide accessibility, the testing prior to new formulation should in particular include an in-depth analysis of those collectives that in the past did not participate in the screening programme, in order to achieve an adequate adaptation to the needs of the involved parties. In the light of a cumulative participation rate of up to $80 \%$ of the entitled population [33], possibly just those social collectives that would

\footnotetext{
${ }^{3}$ WHO, 1986, Charta of 1st international conference on health promotion: "Health promotion aims at a process to enable all people to achieve a high degree of self-determination about their health and thus enable them to improve their health".
}

\section{(6) Erreichen, Inanspruchnahme und umfassende} Information

Für die Gestaltung dieser Elemente im neuen Verfahren sind insbesondere Ergebnisse aus aktueller deutscher Versorgungsforschung von Interesse.

Seitens des Gesetzgebers besteht ein hoher Anspruch: Der Einladung im organisierten Verfahren sind Informationen beizufügen, die die anspruchsberechtigte Person hinreichend, ausgewogen, in einfacher Sprache, zielgruppengerecht und barrierefrei über Nutzen und Risiken bzw. Vor- und Nachteile der jeweiligen Krebsfrüherkennungsmaßnahme aufklären, um ihr eine informierte Entscheidung für oder gegen die Teilnahme an dem Krebsfrüherkennungsprogramm zu ermöglichen. In die Informationen sind auch Erläuterungen zur vorgesehenen Erhebung, Verarbeitung und Nutzung der Daten sowie zu den zum Schutz der Daten getroffenen Maßnahmen aufzunehmen [2]. Da auch bevölkerungsmedizinisch sinnvolle und empfehlenswerte Krebsfrüherkennungsmaßnahmen für gesunde bzw. beschwerdefreie Personen Gesundheitsrisiken beinhalten, soll das Inanspruchnahmeverhalten der einzelnen Person allein durch eine ausreichende, neutrale und verständliche Information und Beratung sowie durch die individuellen Werte und Präferenzen der Person bestimmt sein. Das Ziel einer informierten individuellen Entscheidung ist dem Ziel einer möglichst hohen Teilnahmerate übergeordnet (Krebsfrüherkennungs- und -registergesetz - KFRG). Entsprechend entfällt die gesetzliche Regelung ( $\$ 62$ SGB V), welche die Gewährung einer reduzierten Belastungsgrenze für chronisch Kranke an die regelmäßige Inanspruchnahme einer Krebsfrüherkennungsuntersuchung koppelte. Für die Information der Patientin mit dem Ziel der selbstbestimmten Entscheidung sind deren Umfang und Zeitpunkt nach bisherigen Erkenntnissen mit prägend. Die Befähigung zur selbstbestimmten Entscheidung fällt daher, nach den grundlegenden Prinzipien der Ottawa-Charta ${ }^{3}$, aber auch ausdrücklich gemäß Handlungsfeld 4 (Stärkung der Patientenorientierung) des nationalen Krebsplans, in den ärztlichen Aufgabenbereich und wird in der Folge hohe Ansprüche an die Ausgestaltung von Gesundheitsmündigkeit innerhalb einer neuen Richtlinie stellen.

Welche Auswirkungen hat es z.B., wenn Informationen zum Verfahren mit der Einladung versandt oder separat von der Einladung übermittelt werden? In der Forschung bestehen unterschiedlich einzuordnende Erkenntnisse, wie Einladungsverfahren, Kommunikation und umfassende Information gestaltet sein sollten, um einerseits die Teilnahme möglichst vieler Frauen zu erreichen und andererseits die freie Entscheidungsfindung zu fördern (z.B. MARZY-Studie, Mainz, Studienpopulation: 5000 Frauen im Alter von 30 bis 65 Jahren, die in der Stadt Mainz und dem Kreis Mainz-Bingen in Rheinland-Pfalz wohnhaft sind; gefördert von der Deutschen Krebshilfe [31,32]). Die Gestaltung der Kommunikation ist beispielsweise ein Modul innerhalb der MARZY-Studie.

Um dem Anspruch einer flächendeckenden Zugänglichkeit nachzukommen, ist in die Prüfung vorab zur Neugestaltung, insbesondere eine eingehende Analyse der nicht am bisherigen Screening-Programm teilnehmenden Kollektive, einzubeziehen, um einen passgerechten Zuschnitt auf die Bedürfnisse der Betroffenen zu erzielen. Angesichts einer bestehenden kumulativen Teilnahmerate von bis zu 80\% der Anspruchsberechtigten [33] nehmen möglicherweise gerade soziale Kollektive, die in besonderer Weise von dem Screening pro-

\footnotetext{
3 WHO, 1986, Charta der 1. Internationalen Konferenz zur Gesundheitsförderung: „Gesundheitsförderung zielt auf einen Prozess, allen Menschen ein höheres Maß an Selbstbestimmung über ihre Gesundheit zu ermögli-
} chen und sie damit zur Stärkung ihrer Gesundheit zu befähigen“. 
profit in a special way from the early detection do not participate. Indications for this are given in the international literature (for example, Palencia et al. 2010 [34], Poliquin et al. 2013 [35]). It is known that the incidence of HPV infections depends on, e.g., social status [36] and age [37] to different degrees [38]. For the success of screening it is decisive that the target population does also actually take part. Thus, for instance, special measures should be undertaken to reach those women who have never undergone a screening.

\section{(7) Area coverage}

The nation-wide coverage with all elements of the to be implemented new programme must be guaranteed, its availability has to be checked in advance and if necessary ensured. This requirement for screening procedures for the early detection of cancer diseases has already been made by the WHO in their summary of criteria in 1968 [39]. In the model phase, accordingly, a check has to be included as to how the nation-wide availability of the individual elements of the further developed procedure can be realised, e.g., for differential colposcopy, etc. and involved concepts.

A check of the nation-wide availability or, respectively, provision includes a clarification of cost effectiveness (WHO 1968). To what extent can the existing structures possibly be used or incorporated? Neither the previous results nor the orientation on the key points of an organised screening in the EU guidelines call for a completely new draft.

One can consider, for example, stage models or pathways that can be laid down in the procedure description.

\section{(8) Quality assurance}

According to the EU guidelines, measures for quality assurance are required for the entire process; examples include: taking cervical swab samples (EU GL p. 87,129), cytological examinations (EU GL p. 153), colposcopy (EU GL p. 201), histopathology (EU GL p. 183). This approach aiming for a comprehensive quality system is also the objective of the implementation act. In order to avoid duplicated structures, it should be checked during the elaboration of a quality assurance procedure for organised cervical cancer screening if and how the quality assurance measures already existing in the German health care system can be integrated. These include, e.g., the preliminary work on sector-equal quality assurance for conisation (AQUA) and the procedures of the Associations of Statutory Health Insurance Physicians. Cervical cancer screening can be embedded in a wide-ranging system of quality assurance and control. Various elements already exist, e.g., national regulations have been established for the use of health insurance data for quality assurance. On behalf of the FJC, the AQUA Institute and a cross-sectorial expert committee have developed a sector-equal quality assurance for conisation. The final report from the year 2010 is now available. Further fields from the requirements of the EU guidelines can be included or, respectively, complemented within this framework. In addition, existing measures from the outpatient sector for quality assurance with regard to cervical smear tests can be included and/or used for orientation. Also, the summary statistics and their evaluation on the part of the Associations of SHI-Accredited Physicians or the certification conceptions of the German Cancer Society can be considered for the further development and adaptation of the procedure [33]. Data economy and system compatibility should also be taken into account in the reformulation of quality assurance and fitieren würden, nicht teil. Hinweise hierzu gibt die internationale Literatur (exemplarisch Palencia et al. 2010 [34], Poliquin et al. 2013 [35]). Es ist bekannt, dass sich die Inzidenz der HPV-Infektion in Abhängigkeit von z.B. sozialem Status [36] und Alter [37] unterschiedlich beläuft [38]. Für den Erfolg eines Screenings ist entscheidend, dass die Zielpopulation auch tatsächlich teilnimmt. Deshalb sollten beispielsweise besondere Maßnahmen ergriffen werden, damit Frauen erreicht werden, die noch nie teilgenommen haben.

\section{(7) Flächendeckung}

Eine flächendeckende Versorgung mit allen Elementen des zu implementierenden neuen Programms ist zu gewährleisten, ihre Verfügbarkeit vorab zu überprüfen und ggf. sicherzustellen. Diese Forderung an Screening-Verfahren zur Früherkennung von Krebserkrankungen hat bereits die WHO in einer Kriterienzusammenstellung 1968 [39] eingefordert. In die Modellphase würde demnach auch eine Prüfung einzubeziehen sein, wie eine flächendeckende Versorgung für die einzelnen Elemente des weiterentwickelten Verfahrens erreicht werden kann, z. B. für Differenzialkolposkopie u. a., aufsuchende Konzepte. Die Überprüfung auf flächendeckende Verfügbarkeit bzw. die Bereitstellung beinhaltet eine Klärung der Kosteneffektivität (WHO 1968). Inwieweit sollten vorhandene Strukturen nach Möglichkeit genutzt bzw. einbezogen werden? Weder die bisherigen Ergebnisse noch die Orientierung an Eckpunkten eines organisierten Screenings aus der EU LL erfordern einen kompletten Neuentwurf.

In Betracht kommen beispielsweise Stufenmodelle oder Pfade, die in der Verfahrensbeschreibung festgelegt werden.

\section{(8) Qualitätssicherung}

In den EU-Leitlinie werden über den gesamten Prozess angelegte Qualitätssicherungsmaßnahmen gefordert, als Beispiele sind genannt: Abstrichentnahme (EU-LL S. 87,129), zytologische Untersuchung (EU-LL S. 153), Kolposkopie (EU-LL S. 201), Histopathologie (EU-LL S. 183). Auf diesen Ansatz einer umfassenden Qualitätsdarlegung zielt auch das Umsetzungsgesetz. Zur Vermeidung von Doppelstrukturen sollte bei der Erarbeitung des Qualitätssicherungsverfahrens für das organisierte Zervixkarzinom-Screening geprüft werden, ob und wie bereits im deutschen Versorgungssystem existierende Qualitätssicherungsmaßnahmen integriert werden können. Dazu zählen z.B. die Vorarbeiten zur sektorgleichen Qualitätssicherung für die Konisation (AQUA) und die Verfahren der Kassenärztlichen Vereinigungen. Das Zervixkarzinom-Screening kann in ein weitreichendes System der Qualitätssicherung und -kontrolle eingebettet werden. Verschiedene Elemente bestehen bereits, z. B. hat die Nutzung von Versichertendaten zum Zweck der Qualitätssicherung nationale Regelungen gefunden. Im Auftrag des G-BA wurde durch das AQUA-Institut und eine sektorenübergreifende Expert/innengruppe eine sektorengleiche Qualitätssicherung für die Konisation entwickelt. Der Abschlussbericht aus 2010 liegt vor. Weitere Bereiche aus den Anforderungen der EU-Richtlinie könnten in diesem Rahmen miterfasst und ggf. ergänzt werden. Außerdem können bestehende vertragsärztliche Maßnahmen zur Qualitätssicherung der Abstrichuntersuchung Einbezug finden und/oder zur Orientierung dienen. Auch auf die Übersichtsstatistiken und deren Auswertungen aufseiten der Kassenärztlichen Vereinigungen oder die Zertifizierungskonzeption der Deutschen Krebsgesellschaft kann für die Weiterentwicklung und Anpassung des Verfahrens zurückgegriffen werden [33]. Die Datensparsamkeit und Systemkompatibilität gilt es bei der Umgestaltung der Qualitätssicherung und -transparenz ebenso zu berücksichtigen wie die Möglichkeiten zu sinnvollem Follow-up bis hin zur Evaluation (s.u.). 
transparency as well as the possibilities for meaningful follow-up through to evaluation (see below).

\section{(9) Data management and evaluation agencies, register solutions}

Data management and evaluation agencies will be necessary for the tasks of evaluating the procedure (not only regarding the performance of the process steps but also for its success) and reflections on the system of health care supply. One may consider, e.g., joint facilities of the self-governing bodies at a state level, if necessary associated with existing facilities of the local authorities. Thus it should be examined in good time if and in what context and to what extent the creation of such an agency is possible, especially under the current data protection laws.

In this context, the cooperation/interaction or, respectively, the work allocation with the involvement of cancer registers must also be clarified. This region of necessary clarification also includes considerations about the extent and objectives of register solutions. The draft of the cancer screening and registration law (KFRG) proposes that the federal states should establish state-wide cancer registers. The title of the implementation law assigns cancer registers directly to quality assurance and support. Accordingly the Ministry of Health emphasises the clinical relationship for the proposed register regulations: clinical cancer registers are thereby professionally independent institutions that record all relevant data that arise in the course of cancer disease and its treatment. The data are transferred by the involved health care providers to the clinical cancer registers. Therefore the legal regulations in the cancer screening and registration law require that the clinical cancer registers also record data for the epidemiological cancer register and should pass them on to the latter. Epidemiological cancer registers exist in all federal states with their own legal foundations [40].

The objective of the possibility included in the law for an exemplary check of feasibility and utility should also include as a central item a check as to suitability to promote quality [41]. Length, compatibility of data acquisition with data gathered for other purposes, as well as the principles of data economy and data protection should also be included in the evaluation.

Various European countries still do not have information systems and monitoring. As an alternative "ad-hoc surveys" are proposed in the European guidelines (EU GL p.43-45) [5], whereby in this case also a detailed concept (requirements, data flows, data protection, analysis options, expenditure, synergies) is to be prepared in advance - not least as a basis for evaluation (see below).

\section{(10) Evaluation}

The development of a detailed evaluation concept prior to implementation is required for cervical cancer screening in order to clarify objectives, parameters as well as the extent of the needed data. The definition of the database necessary for a suitable monitoring should take data economy and the avoidance of duplicated acquisition into account as this is especially important for routine practice. Safeguarding the integrity of personal data should also be taken into consideration. Even when the elaboration ultimately lies in the competence of the FJC, the cooperation of selfgoverning bodies and relevant professional societies is assured and appears to allow reasonable considerations in advance [42]. Also the funding programme [43] of the German Ministry of Health proposes support explicitly for accompanying measures for the exemplary testing of organised screening programmes for cervical cancer..., including the identification of supporting and

\section{(9) Datenführende und auswertende Stellen,}

\section{Registerlösungen}

Datenhaltende und -auswertende Stellen werden für Aufgaben der Bewertung des Verfahrens (nicht nur der Durchführung der Prozessschritte, sondern auch seiner Zielerreichung) und die Reflexion im System der Gesundheitsversorgung benötigt. In Betracht kommen z.B. gemeinsame Einrichtungen der Selbstverwaltungspartner auf Landesebene, ggf. angegliedert an eine bestehende Einrichtung der Selbstverwaltung. Es ist daher frühzeitig zu prüfen, ob bzw. in welchem Kontext und Umfang die Einrichtung einer solchen Stelle insbesondere unter den derzeitigen datenschutzrechtlichen Rahmenbedingungen möglich ist.

Zu klären ist in diesem Zusammenhang auch die Zusammenarbeit/ das Zusammenwirken bzw. die Arbeitsaufteilung unter Einbeziehung von Krebsregistern. In diesen Bereich des Klärungsbedarfs fallen Überlegungen über Umfang und Zielsetzung von Registerlösungen. Der Entwurf des Krebsfrüherkennungs- und registergesetzes (KFRG) sieht vor, dass die Länder flächendeckend klinische Krebsregister einrichten sollen. Der Titel des Umsetzungsgesetzes ordnet Krebsregister unmittelbar der Qualitätssicherung - und förderung zu. Entsprechend betont das Bundesministerium für Gesundheit für die vorgesehenen Registerregelungen den klinischen Zusammenhang: Klinische Krebsregister sind dabei fachlich unabhängige Einrichtungen, die alle wichtigen Daten, die im Verlaufe einer Krebserkrankung und ihrer Behandlung anfallen, erfassen. Die Daten werden den klinischen Krebsregistern von den an der Behandlung beteiligten Leistungserbringern übermittelt. Deswegen sieht die gesetzliche Regelung im Krebsfrüherkennungs- und -registergesetz vor, dass die klinischen Krebsregister auch Daten für die epidemiologischen Krebsregister erfassen und an diese weiterleiten sollen. Epidemiologische Krebsregister bestehen in allen Bundesländern auf eigener gesetzlicher Grundlage [40].

Die Zielrichtung der im Gesetz festgehaltenen Möglichkeit modellhafter Prüfung von Machbarkeit und Nutzen hat die Prüfung auf Eignung zur Qualitätsförderung als zentrales Anliegen einzuschließen [41]. Umfang, Kompatibilität der Datenerhebungen mit zu anderen Zwecken erhobenen Daten, die Gebote von Datensparsamkeit und Datenschutz sind ebenfalls in die Bewertung einzubeziehen.

Verschiedene europäische Länder haben noch kein Informationssystem und Monitoring. Als Alternative werden in den Europäischen Leitlinien „ad-hoc surveys“ vorgeschlagen (EU-LL S. 43-45) [5], wobei auch hierfür ein detailliertes Konzept (Anforderungen, Datenflüsse, Datenschutz, Analysemöglichkeiten, Aufwand, Synergien) im Voraus zu erstellen ist - nicht zuletzt als Grundlage der Evaluation (s. u.).

\section{(10) Evaluation}

Für das Zervixkarzinom-Screening bedarf es der Entwicklung eines detaillierten Evaluationskonzepts vor Implementierung des Verfahrens, um Ziele, Parameter sowie den Umfang der erforderlichen Daten zu klären. Die Definition des für ein geeignetes Monitoring nötigen Datenbestands sollte insbesondere der für die Praxis wichtigen Datensparsamkeit und Vermeidung von Doppelerhebungen Rechnung tragen. Der Stellenwert der Wahrung persönlicher Datenhoheit bleibt gleichfalls zu berücksichtigen. Auch wenn die Erarbeitung letztlich im Kontext des G-BA erfolgt, ist die Mitwirkung der Selbstverwaltungspartner und einschlägiger Fachgesellschaften dabei sicher und lässt Überlegungen bereits im Vorfeld sinnvoll erscheinen [42]. Auch das Förderprogramm [43] des Bundesministeriums für Gesundheit hat Förderung explizit für Begleitmaßnahmen zur modellhaften Erprobung von organisierten Screening-Programmen für Zervixkarzinom..., einschließlich der Ermittlung fördernder und hemmender Faktoren zur Teilnahme an organisierten Screening-Programmen vorgesehen. 
inhibiting factors for participation in organised screening programmes.

In the conception of an evaluation, other influencing factors must be taken into account. The close association between cervical cancer and infections with human papilloma virus (HPV) and the availability of a vaccine in perspective hold the prospect of a primary prevention of cervical cancer. An evaluation of screening for cervical cancer can only be made under consideration of this development. Since the middle of 2007 the statutory health insurances have been offering all girls aged between 12 and 17 years a vaccination against $H P V$. In order to record possible effects of the vaccination on the further structure of screening, data on HPV vaccinations should also be documented and taken into account in the total concept of prevention of cervical cancer.

In general, a distinction has to be made between process-evaluating indications and indicators for the success of the screening programme as a whole. It can on the basis of "process measures" be shown that the interim objectives of screening have been achieved. These process and quality indicators, however, are merely indicators about the course of the procedure. The objective achievement of the screening process (referred to the abovementioned objectives) has moreover to be evaluated separately. A modified screening concept must ultimately be judged by the extent to which the recommendations of the European guidelines for a reduction of the disease burden (see above, e.g., mortality of cervical cancer, incidence of precursors) and damage potential (false-positive findings, over diagnosis, over therapy and the associated morbidity including psychological impairment, creation of a false sense of security due to false-negative findings) as well as a cost-effective management can be realised. For the success of a screening programme it is also decisive that the respective target groups do actually participate in it [27].

The quality criteria or, respectively, quality indicators of an evaluation concept must be oriented on these aspects.

\section{Overall Conclusions}

$\nabla$

The national plan calls for an adaptation of the cervical cancer screening to meet the quality requirements of the current edition of the "European Guidelines for Quality Assurance in Cervical Cancer Screening". To this end, the existing options for cervical cancer screening need to be developed further. The previous procedure has proven to be successful and has contributed to an appreciable reduction in the rates of new cases and deaths. The adaptation now contains an organisational further development and in part a new organisation of the already existing screening for cervical cancer. Central steps here are an improvement of quality assurance, establishment of an organised invitation procedure, adjustment of the screening intervals, regulation of follow-up in cases of remarkable findings and establishment of an information system for monitoring and evaluation purposes. These innovations should be carried out within an organised, population-based framework.

The aim of this new organisation is to achieve a further reduction in the incidence and mortality of cervical cancer in Germany while minimising the risks and optimising the benefits of the procedure. The cancer screening and registration law defines the framework for this reorganisation. The Federal Joint Committee is designated as the central actor.

When the national cancer plan is considered as a concept for the discursive further development of health care, then the experts
Bei der Konzeption der Evaluation müssen weitere Einflussfaktoren berücksichtigt werden. Die enge Assoziation zwischen Zervixkarzinom und Infektionen mit humanen Papillomaviren (HPV) und die Verfügbarkeit einer Impfung stellen perspektivisch eine Primärprävention des Zervixkarzinoms in Aussicht. Eine Bewertung des Screenings auf Zervixkarzinom kann nur unter Berücksichtigung dieser Entwicklungen erfolgen. Die gesetzlichen Krankenkassen bieten seit Mitte 2007 für alle Mädchen im Alter von 12 bis 17 Jahren die Impfung gegen HPV an. Um mögliche Auswirkungen der Impfung auf die weitere Gestaltung der Früherkennung erfassen zu können, sollten auch Daten zur HPV-Impfung dokumentiert und im Gesamtkonzept der Prävention des Zervixkarzinoms berücksichtigt werden.

Grundsätzlich ist $\mathrm{zu}$ unterscheiden zwischen prozessbewertenden Indikatoren und Indikatoren für den Erfolg des Screening-Programms insgesamt. Es kann anhand von „process measures“ gezeigt werden, dass die Zwischenziele des Screenings erreicht werden. Diese Prozess- und Qualitätsindikatoren sind jedoch lediglich Hinweise zum Verfahrensablauf. Die Zielerreichung des Screening-Verfahrens (gemessen an den eingangs genannten Zielsetzungen) ist darüber hinaus gesondert zu evaluieren:

Eine geänderte Screening-Konzeption muss sich letztendlich daran messen lassen, inwieweit mit den Empfehlungen der Europäischen Leitlinie eine Senkung der Krankheitslast (s. o., z. B. Mortalität bei Zervixkarzinom, Inzidenz von Vorstufen) und des Schadenspotenzials (falsch positive Befunde, Überdiagnostik, Übertherapie und dadurch verursachte Morbidität einschließlich psychischer Beinträchtigung, Vermittlung einer falschen Sicherheit durch falsch negative Befunde) sowie eine kosteneffektivere Versorgung erreicht werden kann. Für den Erfolg eines Screening-Programms ist es auch maßgebend, dass die jeweilige Zielpopulation tatsächlich teilnimmt [27].

Daran sind die Qualitätskriterien bzw. -indikatoren einer Evaluationskonzeption zu orientieren.

\section{Zusammenfassende Schlussfolgerungen}

$\nabla$

Der nationale Krebsplan sieht die Anpassung der ZervixkarzinomFrüherkennung an die Qualitätsvorgaben der aktuellen Auflage der „Europäischen Leitlinien für die Qualitätssicherung des Zervixkarzinom-Screenings" vor. Dazu soll das bestehende Angebot zur Zervixkarzinom-Früherkennung weiterentwickelt werden. Das bisherige Verfahren hat sich als erfolgreich erwiesen und zu einer beträchtlichen Senkung der Neuerkrankungs- und Sterblichkeitsraten beigetragen. Die Anpassung beinhaltet nun eine organisatorische Weiterentwicklung und teilweise Neuorganisation der bereits etablierten Zervixkarzinom-Früherkennung. Zentrale Schritte sind hierbei die Verbesserung der Qualitätssicherung, Durchführung eines organisierten Einladungsverfahrens, Anpassung des Screening-Intervalls, die Regelung des Follow-ups der auffälligen Befunde und die Etablierung eines Informationssystems für das Monitoring und die Evaluation. Diese Neuerungen sollen in einem organisierten, bevölkerungsbezogenen Rahmen durchgeführt werden.

Ziel dieser Neuorganisation ist eine weitere Senkung der Inzidenz und Mortalität des Zervixkarzinoms in Deutschland bei Minimierung der Risiken und Optimierung des Nutzens des Verfahrens. Das Krebsfrüherkennungs- und -registergesetz legt den Rahmen für die Umgestaltung fest. Darin ist der Gemeinsame Bundesausschuss als zentral Handelnder vorgesehen.

Versteht man den Nationalen Krebsplan als Konzept einer diskursiven Weiterentwicklung der Versorgung, so sind für die Anteile, die zur Änderung vorgesehen bzw. empfohlen sind, die Expert/innen für 
for the respective problems out of the different fields of the health care system should be called upon to address those parts of the system for which changes are required or recommended. Partners of the self-governing bodies are represented in the subcommittees of the FJC. In addition external experts may be requested to give their opinions on specific questions. Furthermore, as a general rule, the respective professional societies will be consulted concerning the procedures. The contents of the process to be carried out under the guidance of the FJC may be elaborated in advance in individual steps by the relevant professional societies. First of all, consensus within the medical field must be achieved in order to be able to participate in the process leading to a new version of the early detection directive that will define the procedure in Germany. The presented overview of the forthcoming fields of action may serve as a basis for the development process and for the work of the interdisciplinary ${ }^{4}$ task force. This framework also opens the possibility in the further course to follow the activities of the specialists in the various committees and to coordinate them towards a target consensus. The sharing process regarding upcoming research tasks and model projects can be voted upon here, and contacts to the guideline commission of the DGGG can be intensified. Furthermore the inclusion of a watch dog function would be desirable to continuously bring together current study results from national model projects and trials as well as internationally obtained findings. Periodic reports to the boards of the professional societies and to congresses would finally enable, if necessary, a modification of the activities to be initiated early in light of consensus targets and steps, transparency to be achieved in the specialty, and to hold a scientific discussion to accompany the process.

The heterogeneity of the approaches in Europe (even within individual countries) and of the results clearly illustrate that Germany must seek and define its own pathway.

\section{Conflict of Interest}

$\nabla$

Ein Interessenkonflikt besteht nicht.

\section{Affiliations}

${ }^{1}$ Universitätsfrauenklinik Tübingen, Institut für Frauengesundheitsforschung, Tübingen

2 Frauenklinik, Universitätsklinikum, Erlangen

${ }^{3}$ Klinik für Frauenheilkunde und Geburtshilfe, Caritas Krankenhaus St. Josef, Regensburg

${ }^{4}$ Berufsverband der Frauenärzte, Hannover

\section{References}

1 Bundesministerium für Gesundheit. Nationaler Krebsplan. Handlungsfelder, Ziele und Umsetzungsempfehlungen. www.bundesgesundheitsministerium.de; last access: 02.12.2012

2 Bundesministerium für Gesundheit. Krebsfrüherkennungs- und -registergesetz (KFRG), Entwurf. www.bundesgesundheitsministerium.de; last access: 02.12.2012

3 Gemeinsamer Bundesausschuss. Richtlinie des Gemeinsamen Bundesausschusses über die Früherkennung von Krebserkrankungen (Krebsfrüherkennungs-Richtlinie/KFE-RL) in der Fassung vom 18. Juni 2009, veröffentlicht im Bundesanzeiger 2009, Nr.148a, zuletzt geändert am 16. Dezember 2010, veröffentlicht im Bundesanzeiger 2011; Nr.34: S. 864, in Kraft getreten am 3. März 2011. http://www.g-ba.de/

\footnotetext{
${ }^{4}$ For example, with cooperation of the professional society of gynaecologists and obstetricians, board members of the professional societies, members of oncological working groups in the professional societies, etc.
}

diese Fragestellung aus den unterschiedlichsten Bereichen des Versorgungssystems zur Mitarbeit und Ausgestaltung aufgefordert.

In den Gremien des G-BA sind die Partner der Selbstverwaltung vertreten. Hinzu kommen Sachverständige, die zu bestimmten Fragen Expertise einbringen. Außerdem werden in der Regel die betroffenen Fachgesellschaften zum Vorgehen gehört. Der vom G-BA federführend durchzuführende Prozess kann inhaltlich in den einzelnen Schritten von den Fachgesellschaften frühzeitig vorbereitet werden. Um im Prozess hin zu einer Neufassung der Früherkennungs-Richtlinie, die das Vorgehen in der Bundesrepublik festlegen wird, mitgestalten zu können, bedarf es zunächst eines Zusammenfindens im Fachgebiet. Die vorgestellte Zusammenschau anstehender Handlungsfelder könnte als Grundlage für den Findungsprozess und die Arbeit einer sektorübergreifenden ${ }^{4}$ Task Force dienen. Dieser Rahmen würde es im weiteren Verlauf auch erlauben, die Aktivitäten von Fachvertreter/innen in unterschiedlichen Gremien zu begleiten und auf eine konsentierte Zielsetzung hin zu koordinieren. Die Übernahme aktuell anstehender Forschungsaufgaben und Modellvorhaben könnte hier abgestimmt werden, ein Kontakt zur Leitlinien-Kommission der DGGG gepflegt werden. Darüber hinaus wäre die Übernahme einer Watch-Dog-Funktion wünschenswert, die aktuelle Studienergebnisse aus nationalen Modellprojekten und Studien sowie internationalen Erkenntnisgewinn kontinuierlich zusammenführt. Periodische Berichte an die Vorstände von Fachgesellschaften und Berufsverband sowie auf Kongressen würden es schließlich erlauben, nötigenfalls ein frühzeitiges Modifizieren der Aktivitäten mit Blick auf die konsentierten Ziele und Schritte einzuleiten, Öffentlichkeit im Fachgebiet herzustellen und eine prozessbegleitende fachliche Diskussion ermöglichen.

Die Heterogenität der Ansätze in Europa (selbst innerhalb einzelner Länder), ebenso wie der Ergebnisse, lassen deutlich werden, dass Deutschland seinen eigenen Weg zu suchen und zu definieren hat.

4 Bundesministerium für Gesundheit. Ziele-Papiere des Nationalen Krebsplans. http://www.bmg.bund.de/praevention/nationalerkrebsplan/was-haben-wir-bisher-erreicht.html; last access: 02.12.2012

5 European Commission. European guidelines for quality assurance in cervical cancer screening. 2nd ed. 2008. http://bookshop.europa.eu/ en/european-guidelines-for-quality-assurance-in-cervical-

cancerscreening-ptND7007117/; last access: 28.02.2013

6 BMG. Informationen zum Gesetz zur Weiterentwicklung der Krebsfrüherkennung und zur Qualitätssicherung durch klinische Krebsregister (KFRG).- Regelungsteil „Krebsfrüherkennung“, Anlage 1. http:// www.bmg.bund.de/fileadmin/dateien/Pressemitteilungen/2012/ 2012_03/120822_PM_61_Anlage_1_BMG_Infopapier_KFRG_ Krebsfueherkennung.pdf; last access: 07.01.2013

7 Bundesministerium für Gesundheit. Pressemitteilung 01.02.2013. Bedeutender Tag für die Krebsbekämpfung - Krebsfrüherkennungs- und -registergesetz vom Deutschen Bundestag beschlossen. http://www. bmg.bund.de/ministerium/presse/pressemitteilungen/2013-01/ kfrg-vom-bundestag-beschlossen.html; last access: 08.03.2013

8 Schneider V. Gynäkologische Krebsvorsorge in Deutschland. Pathologe 2012; 33: 286-292

\footnotetext{
${ }^{4}$ Beispielweise unter Beteiligung des Berufsverbandes der Frauenärzte, von Vorstandsmitgliedern der Fachgesellschaft, von Mitgliedern der onkologisch ausgerichteten Arbeitsgruppen in der Fachgesellschaft u.a.
} 
9 Wentzensen N, Klug S. Früherkennung des Zervixkarzinoms. Suche nach einem Gesamtkonzept. DÄB 2008; 105: 617-622

10 Wrigth jr. TC. Cervical cancer screening in the 21st century: is it time to retire the PAP smear? Clin Obstet Gynecol 2007; 50: 313-323

11 Stellungnahme der AWMF zum Entwurf eines Gesetzes zur Umsetzung von Empfehlungen des Nationalen Krebsplans (Krebsplan-Umsetzungsgesetz). http://www.awmf.org/die-awmf/awmf-aktuell/detail/ news/abstracts-der-g-i-n-conference-2012-sind-online-kopie-1. html; last access: 02.12.2012

12 Bundesministerium für Gesundheit. Referentenentwurf des Bundesministeriums für Gesundheit, Entwurf eines Gesetzes zur Umsetzung von Empfehlungen des nationalen Krebsplans (Krebsplan-Umsetzungsgesetz). http://www.bmg.bund.de/fileadmin/dateien/ Downloads/Gesetze_und_Verordnungen/Laufende_Verfahren/K/ Krebsplan/Referentenentwurf_Krebsplan_Umsetzungsgesetz_120702. pdf; last access: 02.12.2012

13 AWMF. Leitlinien. http://www.awmf.org/leitlinien/detail/anmeldung/ 1/11/015-027OL.html; last access: 05.03.2013

14 IQWIG. [S10-01] Nutzenbewertung des HPV-Tests im Primärscreening des Zervixkarzinoms. 1/2012. https://www.iqwig.de/s10-01nutzenbewertung-des-hpv-tests-im.986.html?

tid=1267\&phlex_override_command=element\&random=ceadc2; last access: 02.12 .2012

15 Agency for Healthcare Research and Quality, U.S. Department of Health and Human Services. Screening for cervical cancer. 3/2012. http:// www.uspreventiveservicestaskforce.org/uspstf/uspscerv.htm; last access: 02.12 .2012

16 Campbell NC, Murray E, Darbyshire J et al. Designing and evaluating complex interventions to improve health care. BMJ 2007; 334: 455459

17 Antilla A, von Karsa L, Aasmaa A et al. Cervical cancer screening policies and coverage in Europe. Eur J Cancer 2009; 45: 2649-2658

18 Ronco G, van Ballegooijen M, Becker $N$ et al. Process performance of cervical cancer screening programmes in Europe. Eur J Cancer 2009; 45: 2659-2670

19 Nicula FA, Anttila A, Neamtiu L et al. Challenges in starting organized screening programmes for cervical cancer in the new member states of the European Union. Eur J Cancer 2009; 45: 2679-2684

20 Arbyn M, Raifu AO, Weiderpass E. Trends of cervical cancer mortality in the member states of the European Union. Eur J Cancer 2009; 45: 2640-2648

$21 O E C D$. Screening, survival and mortality of cervical cancer. In: Health at a glance. Europe 2010. OECD Publishing. http://dx.doi.org/10.1787/ health_glance_2010_en; last access: 24.04.2013

22 OECD Screening, survival and mortality for cervical cancer. In: Health at a glance. Europe: OECD Publishing; 2012; http://dx.doi.org/ $10.1787 / 9789264183896-46-e n$

23 Owoc A, Cveijc R, Koprowicz A et al. Reporting rates for cervical screening in the Szczecin Region during the period 2007-2010. Ann Agric Environ Med 2012; 19: 686-691

24 Andrae B, Andersson TML, Lambert PC et al. Screening and cervical cancer cure: population based cohort study. BMJ 2012; 344: e900

25 Hawkes $N$. New screening tests for bowel and cervical cancer are to be piloted in NHS. BMJ 2012; 345: e8455

26 Parkin DM, Bray F, Ferlay J et al. Global cancer statistics, 2002. CA Cancer J Clin 2005; 55: 74-108; http://onlinelibrary.wiley.com/doi/ $10.3322 /$ canjclin.55.2.74/pdf

27 BMG. Öffentliche Bekanntmachung des Bundesministeriums für Gesundheit (BMG) im Rahmen der Ressortforschung „Forschung im Nationalen Krebsplan“ vom 20. Juni 2011. http://www.dlr.de/pt/ Portaldata/45/Resources/dokumente/gesundheitsforschung/ Bekanntmachung_Forschung_im_Nationalen_Krebsplan.pdf; last access: 02.12.2012
28 Vortrag Dr. Dominik Dietz, BMG, 02.03.2010

29 Klug SJ, Taylor KJ, Scheidemann-Wesp $U$ et al. Participation in cervical cancer screening in Germany. Prev Med 2010; 51: 431-432

30 Bundesministerium für Gesundheit. Infopapier KFRG, Anlage 2. http:// www.bmg.bund.de/fileadmin/dateien/Pressemitteilungen/2012/ 2012_03/120822_PM_61_Anlage_2_BMG_Infopapier_KFRG_ Klinische_Krebsregister.pdf; last access: 05.03.2013

31 MARZY-Studie. Machbarkeitsstudie zur Früherkennung des Zervixkarzinoms. http://www.imbei.uni-mainz.de/marzy/index.html; last access: 02.10 .2012

32 Klug S, Bussas U, Dik N et al. Bevölkerungsbezogene typspezifische Prävalenz Humaner Papillomaviren (HPV) in Deutschland vor Einführung der HPV-Impfung. 54. Jahrestagung der Deutschen Gesellschaft für Medizinische Informatik, Biometrie und Epidemiologie e.V. (GMDS). Meeting-Abstract. http://www.egms.de/static/de/meetings/gmds 2009/09gmds038.shtml; last access: 05.03.2013

33 Zentralinstitut für die kassenärztliche Versorgung in der Bundesrepublik Deutschland Abschlussbericht. Durchführung einer versichertenbezogenen Untersuchung zur Inanspruchnahme der Früherkennung auf Zervixkarzinom in den Jahren 2002, 2003 und 2004 auf der Basis von Abrechnungsdaten. 2008. http://195.149.76.250/cms/fileadmin/ images/content/PDFs_alle/Diskussionspapier_ZervixCA.pdf; last access: 02.12.2012

34 Palencia L, Espelt A, Rodriguez-Sanz $M$ et al. Socio-economic inequalities in breast and cervical cancer screening practices in Europe: influence of the type of screening program. Int J Epidemiol 2010; 39: 757765

35 Poliquin K, Decker AD, Altman R et al. Changes in cervical cancer screening behavior for women attending Pap Test Week clinics. Int J Women's Health 2013; 5: 141-148

36 Hillemanns P, Soergel P. Läßt sich das Zervixkarzinom verhindern? Aktueller Stand der HPV-Impfung. best practice onkologie 2010; 5: 28-35

37 Deutsches Krebsforschungszentrum; Krebsinformationsdienst. Humane Papillomviren als Krebsauslöser. http://www.krebsinformationsdienst.de/vorbeugung/risiken/hpv.php\#inhalt17; last access: 08.03.2013

38 Benard VB, Johnson CJ, Thompson TD et al. Examining the association between socioeconomic status and potential human papillomavirusassociated cancers. Centers for Disease Control and Prevention, National Center for Chronic Disease Prevention and Health Promotion, Atlanta, Georgia 30341, USA; vdb9@cdc.gov; last access: 08.03.2013

39 Wilson JMG, Jungner G. Principles and practice of screening for disease Public health paper Number 34. Geneva: WHO; 1968

40 BMG. Informationen zum Gesetz zur Weiterentwicklung der Krebsfrüherkennung und zur Qualitätssicherung durch klinische Krebsregister (KFRG) - Regelungsteil „Klinische Krebsregister“, Anlage 2. http:// www.bmg.bund.de/fileadmin/dateien/Pressemitteilungen/2012/ 2012_03/120822_PM_61_Anlage_1_BMG_Infopapier_KFRG_ Krebsfueherkennung.pdf; last access: 07.01.2013

41 Simoes E, Boukamp K, Mayer ED et al. Gibt es Belege für den Impact qualitätssichernder/-fördernder Verfahren in anderen Ländern? Gesundheitswesen 2004: 66: 361-369

42 Simoes E, Brucker S, Beckmann MW et al. Cervical cancer screening: defining the need for research. Geburtsh Frauenheilk 2013; 73: 239-246

43 BMG. Öffentliche Bekanntmachung des Bundesministeriums für Gesundheit (BMG) im Rahmen der Ressortforschung „Forschung im Nationalen Krebsplan“ vom 20. Juni 2011. http://www.dlr.de/pt/ Portaldata/45/Resources/dokumente/gesundheitsforschung/Bekanntmachung_Forschung_im_Nationalen_Krebsplan.pdf; last access: 02.12 .2012

Deutschsprachige Zusatzinformationen online abrufbar unter: www.thieme-connect.de/ejournals/toc/gebfra. 